\title{
Flooding Regime Impacts on Radiation, Evapotranspiration, and Latent Energy Fluxes over Groundwater-Dependent Riparian Cottonwood and Saltcedar Forests
}

\author{
James Cleverly, ${ }^{1,2}$ James R. Thibault, ${ }^{1}$ Stephen B. Teet, ${ }^{1,3}$ Paul Tashjian, ${ }^{4}$ \\ Lawrence E. Hipps, ${ }^{5}$ Clifford N. Dahm, ${ }^{1}$ and Derek Eamus ${ }^{2,6}$ \\ ${ }^{1}$ Department of Biology, University of New Mexico, Albuquerque, NM 87131, USA \\ ${ }^{2}$ Australian SuperSite Network and Terrestrial Ecohydrology Research Group, School of Life Sciences, University of Technology Sydney, \\ P.O. Box 123, Broadway, NSW 2007, Australia \\ ${ }^{3}$ USDA Agricultural Research Service, Grazinglands Research Laboratory, 7207 West Cheyenne Street, El Reno, OK 73036, USA \\ ${ }^{4}$ U.S. Fish and Wildlife Service, National Wildlife Refuge System, Division of Water Resources, \\ 500 Gold SW, Albuquerque, NM 87102, USA \\ ${ }^{5}$ Department of Plants, Soils and Biometeorology, Utah State University, Logan, UT 84322, USA \\ ${ }^{6}$ National Centre for Groundwater Research and Training, University of Technology Sydney, \\ P.O. Box 123, Broadway, NSW 2007, Australia
}

Correspondence should be addressed to James Cleverly; james.cleverly@uts.edu.au

Received 2 March 2015; Accepted 19 April 2015

Academic Editor: Marcos Heil Costa

Copyright (C) 2015 James Cleverly et al. This is an open access article distributed under the Creative Commons Attribution License, which permits unrestricted use, distribution, and reproduction in any medium, provided the original work is properly cited.

\begin{abstract}
Radiation and energy balances are key drivers of ecosystem water and carbon cycling. This study reports on ten years of eddy covariance measurements over groundwater-dependent ecosystems (GDEs) in New Mexico, USA, to compare the role of drought and flooding on radiation, water, and energy budgets of forests differing in species composition (native cottonwood versus nonnative saltcedar) and flooding regime. After net radiation $\left(700-800 \mathrm{~W} \mathrm{~m}^{-2}\right)$, latent heat flux was the largest energy flux, with annual values of evapotranspiration exceeding annual precipitation by 250-600\%. Evaporative cooling dominated the energy fluxes of both forest types, although cottonwood generated much lower daily values of sensible heat flux $\left(<-5 \mathrm{MJ} \mathrm{m} \mathrm{m}^{-2} \mathrm{~d}^{-1}\right)$. Drought caused a reduction in evaporative cooling, especially in the saltcedar sites where evapotranspiration was also reduced, but without a substantial decline in depth-to-groundwater. Our findings have broad implications on water security and the management of native and nonnative vegetation within semiarid southwestern North America. Specifically, consideration of the energy budgets of GDEs as they respond to fluctuations in climatic conditions can inform the management options for reducing evapotranspiration and maintaining instream flow, which is legally mandated as part of interstate and international water resources agreements.
\end{abstract}

\section{Introduction}

Partitioning of surface energy fluxes is a robust method for estimating landscape evapotranspiration (ET). It is only with widespread use of eddy covariance (EC) techniques in the last few decades that all primary fluxes can be directly measured $[1,2]$. Although some of the largest rates of ET in arid and semiarid landscapes originate from riparian groundwaterdependent ecosystems (GDEs) [3, 4], measurements of energy fluxes using EC techniques in riparian ecosystems are rare because of their narrow fetch (i.e., the upwind distance of homogenous vegetation required for flux measurements) and stable conditions under advection $[5,6]$. Rivers also have an important effect on local surface energy fluxes within narrow riparian forests by increasing turbulence, augmenting surface fluxes, and controlling the direction of surface energy fluxes [4].

Energy is transported via three mechanisms: radiation, conduction, and convection [7]. In terrestrial ecosystems, these processes are represented by the flux of net radiation 
$\left(Q^{*}\right)$, the flux of heat with the ground via conduction $\left(Q_{G}\right)$, and turbulent transport, which includes the fluxes of sensible $\left(Q_{H}\right)$ and latent heat $\left(Q_{E}\right)[8] . Q^{*}$ is determined as the difference between downwelling and upwelling radiation in the short (visible and solar) and long (infrared and thermal) wavelengths. $Q_{G}$ can be highly variable at a given location, especially across habitats (e.g., from under shrub to bare soil) in semiarid regions [9] or in response to flooding [10]. However, $Q_{G}$ tends to be small under the shade of a deep canopy [11] and when averaged over a day [12].

Observations of energy fluxes contribute to our understanding of world climate and also to our understanding of the behaviour of different forest types. Wilson et al. [2], for example, compare partitioning between $Q_{H}$ and $Q_{E}$ over a number of different vegetated surfaces in the Ameriflux data set. By comparing Bowen ratios ( $\beta$ : the ratio of sensible to latent energy fluxes; $\left.\beta=Q_{H} / Q_{E}\right)$, distinctions were demonstrated between vegetation type and climate, with the smallest $\beta$ in agricultural and deciduous forest ecosystems and largest in coniferous and grassland ecosystems with a distinct dry climate [2]. Arid sites typically have larger $\beta$ than mesic sites, except when under irrigation [13], and $\beta$ can exceed four (i.e., $Q_{H}$ is four times larger than $Q_{E}$ ) over an arid, bare soil clay pan [14]. Energy partitioning is also valuable for observing changes in response to invasion by nonnative species [15].

Water resources in the Rio Grande are governed by an interstate compact between Colorado, New Mexico, and Texas and by a treaty between the USA and Mexico [11, 16, 17]. Demand for water is larger than the allocations dictated in the compact and treaty, but adjudication of water rights is ongoing and mostly incomplete. As an initial step, a water budget was compiled to assist with enforcing legal obligations and to design and implement sustainable water policy [18]. Open water evaporation and ET from groundwaterdependent vegetation (i.e., plants that have their roots in contact with groundwater; phreatophytes) and agriculture dominate the water budget of the Middle Rio Grande [19]. Given the importance of in-stream flow and ET in the water budget, a better understanding of the energetic constraints on these ecosystems will provide improved water security during times of both scarcity and abundance. The two key aims of the work described herein are to (1) provide an analysis of the energy budget of two forest types along the Rio Grande (dominated by either a native or introduced species) and (2) examine the impacts of drought and floods on the energy budgets of these sites. Such studies will improve our ability to manage water resources sustainably across this extensive catchment and to determine strategies to achieve desired outcomes from managed changes in land use.

Increased vegetation density and cover along the Rio Grande over the past century or more has generated riparian forests with extensive fetch [11, 20, 21]. Forests extend for several kilometers parallel to the river's general northsouth axis and for hundreds of meters perpendicular to the river. This paper takes a meteorological perspective to present analyses of water and energy fluxes over riparian GDEs situated along the Middle Rio Grande of central New Mexico, USA $[3,11]$. Surface energy fluxes on cloud-free days were compared above native (cottonwood) and nonnative (saltcedar) vegetation. Changes in energy balance in response to flooding and drought were evaluated. We hypothesized that (1) annual rates of ET differ across the two forest types; (2) advection and evaporative cooling, identified by $Q_{H}$ directed toward the surface (i.e., $Q_{H}<0$ ), would be common during wet periods; (3) $Q_{H}$ would increase at the expense of $Q_{E}$ during drought; and (4) $Q_{G}$ would be insignificant under vegetated canopies [11] except during inundation, which would largely affect $Q_{G}$. For convenience, a list of symbols and abbreviations is provided in the Symbols and Abbreviations section.

\section{Methods}

2.1. Site Network. This study focused upon four sites in the riparian corridor along the Middle Rio Grande, New Mexico (Table 1). The shallow slope of the central valley promotes expansion of the riparian corridor, which reaches to over a kilometre in width [3]. Two of these sites host forests dominated by a mature cottonwood canopy (native, Populus deltoides ssp. wislizeni); the other two sites contain stands dominated by saltcedar (nonnative, Tamarix chinensis). One each of the cottonwood and saltcedar forests received regular flooding with a two- to three-year recurrence interval, whilst the complementary pair of sites have not flooded in the last 20 years or more (Table 1). Reference to each site will be made by its dominant species (i.e., cottonwood, saltcedar) and interflood interval (IFI), for example, cottonwood longIFI or cottonwood short-IFI (Table 1).

Eddy covariance systems were mounted from towers in the saltcedar sites beginning in 1999 and in the cottonwood sites during $2000[3,19]$. The tower at the cottonwood shortIFI site was destroyed by vandalism during spring 2004, at which time the site was abandoned and the data record concluded in 2003 (Table 1). At the cottonwood long-IFI site, the understory vegetation was mechanically removed in 2003 [22]. Then, in 2007, a fire burned a substantial portion of the cottonwood canopy at the long-IFI site, after which a crown fell on the tower in 2008, thereby toppling it. The cottonwood long-IFI site was subsequently abandoned that year.

Towers in the cottonwood forests were $25 \mathrm{~m}$ tall. Towers in the saltcedar forest were either $15 \mathrm{~m}$ (short-interval flooding) or $10 \mathrm{~m}$ (long-interval flooding) tall. Footprints of upwind measurements are about $50 \mathrm{~m}$ over saltcedar stands and up to $200 \mathrm{~m}$ over cottonwood stands [11].

2.2. Instruments and Measurements. Radiative, conductive, and turbulent energy fluxes were measured at each of these four riparian sites. Initially, three-dimensional sonic eddy covariance (3SEC) systems consisting of a CSAT3 sonic anemometer to measure wind speed in each of three dimensions $(u, v$, and $w)$, a KH20 Krypton Hygrometer to measure humidity, and a CR23X (Campbell Scientific, Inc.) Logan, UT) datalogger to run the system and collect $30 \mathrm{~min}$ flux and meteorological data were installed at all sites [11, 19]. As funds became available, most systems were upgraded (1) to replace the $\mathrm{KH} 20$ with a fast response, open-path infrared gas analyzer (IRGA, LI-7500, LiCor, Inc., Lincoln, $\mathrm{NE}$ ) measuring carbon and water vapour density and (2) to 
TABLE 1: Flux sites operating in the Middle Rio Grande valley node of NM-EPSCoR Fluxnet.

\begin{tabular}{lcccccc}
\hline Code & Location & Years & IFI $^{\mathrm{a}}$ & $h_{c}(\mathrm{~m})$ & $z-d(\mathrm{~m})$ & $\rho_{d}\left(\mathrm{~g} \mathrm{~cm}{ }^{-3}\right)$ \\
\hline CW & $34.96^{\circ} \mathrm{N}, 106.68^{\circ} \mathrm{W}, 1497 \mathrm{~m}$ asl (Albuquerque, NM) & $2000-2007$ & Long & 23.5 & 9.9 & 1.033 \\
$\mathrm{CW}$ & $34.59^{\circ} \mathrm{N}, 106.75^{\circ} \mathrm{W}, 1459 \mathrm{~m}$ asl (Belen, NM) & $2000-2003$ & Short & 25.1 & 10.5 & 0.957 \\
\hline SC & $34.27^{\circ} \mathrm{N}, 106.87^{\circ} \mathrm{W}, 1427 \mathrm{~m}$ asl (Sevilleta NWR) & $1999-2010$ & Long & 5.2 & 3.4 & 1.280 \\
SC & $33.78^{\circ} \mathrm{N}, 106.88^{\circ} \mathrm{W}, 1375 \mathrm{~m}$ asl (Bosque del Apache NWR) & $1999-2010$ & Short & 6.2 & 4.1 & 1.140 \\
\hline
\end{tabular}

${ }^{\mathrm{a}}$ Short: $2-3$ years; long: $>20$ years.

replace the CR23X with a CR5000 that is capable of storing $10 \mathrm{~Hz}$ measurements along with the $30 \mathrm{~min}$ flux data. A 3SEC system was mounted on the south face of each tower, 2$2.5 \mathrm{~m}$ above the canopy $[3,11,19]$. KH20s were mounted sidenormal to prevent accumulation of water ponding on the mirror following precipitation. IRGAs were rotated $15^{\circ}$ to the north of vertical to avoid solar reflection spikes [23].

In addition to the 3SEC systems, a suite of instruments for measuring energy balance and micrometeorology were mounted upon or near each tower. Temperature $(T)$ and relative humidity were measured at the modal canopy height (HMP45C; Campbell Scientific, Inc., Logan, UT). Precipitation, ground heat flux in two locations beneath the canopy, spatially averaged soil temperature, and soil water content were also measured on a 30-minute basis (TE525, HFT3, TCAV, and CS616, resp.; Campbell Scientific, Inc., Logan, UT). Each system included two atmospheric pressure $(P)$ sensors. TE525s were mounted near the top of the towers. Soil instruments were placed at standard depths: HFT3s $8 \mathrm{~cm}$ below surface, TCAVs $2 \mathrm{~cm}$ and $6 \mathrm{~cm}$, and CS616 inserted horizontally at a depth of $2.5 \mathrm{~cm}$.

The soil dielectric constant as measured by the CS616 is a function of soil water content $(\Theta)$, salinity, temperature, texture, and compaction $[24,25]$. Thus, accurate measurement of $\Theta$ requires sensor calibration to local soil conditions. Measurements on a volumetric basis $\left(\Theta_{v}\right)$ were corrected using an empirical calibration curve against soil water content of samples collected in situ. The upper value of $\Theta_{v}$ measured under flooding conditions was assumed to equal porosity by discounting unmeasured changes due to deflocculation of clay during wetting. Measurements of $\Theta_{v}$ were converted to $\Theta_{g}$ (mass-basis) to match units for determination of soil heat storage. During periods when $\Theta_{g}$ was unavailable, $\Theta_{g}$ was assumed to be equal to long-term average values during periods of comparable wetness at the same site, defined as periods with similar drought index values.

Average $Q_{G}$ at the surface from the two sensors was computed to account for soil heat storage above the sensors utilizing the soil water content $\left(\Theta_{q}\right)$ and the change in soil temperature [26]. Assuming that floodwater was in thermal equilibrium with the soil below, heat storage in floodwater was added to soil heat storage:

$$
\begin{aligned}
Q_{G}= & Q_{G_{8 \mathrm{~cm}}} \\
& +\left(\rho_{b}\left(C_{s}+C_{w} \Theta_{g}\right) d z_{G}+\rho_{w} C_{w} d z_{\text {flood }}\right) \frac{d T_{s}}{d t},
\end{aligned}
$$

where $\rho_{b}$ is the site-specific soil bulk density, $\rho_{w}$ is the density of water, $C_{s}\left(840 \mathrm{~J} \mathrm{~kg}^{-1} \mathrm{~K}^{-1}\right)$ and $C_{w}\left(4180 \mathrm{~J} \mathrm{~kg}^{-1} \mathrm{~K}^{-1}\right)$ are the soil and water heat capacities, respectively, and $d T_{s} / d t$ is the change in soil temperature with respect to measurement period. Heat storage is scaled by depth of ground heat flux plates $\left(d z_{G}=0.08 \mathrm{~m}\right)$ and floodwater depth $\left(d z_{\text {flood }}\right)$.

Initially, $Q^{*}$ was measured well above the canopy with a vented and cross-calibrated net radiometer (REBS-Q7.1, Radiation and Energy Balance, Inc., Seattle, WA). As with the 3SEC systems, radiometry measurements were upgraded as funding became available. First, a CM3 pyranometer measuring downwelling shortwave radiation $\left(Q_{s}\right)$ was added until net radiometers could be replaced. Both saltcedar sites were upgraded with CNR1 component radiometric sensors, measuring both incoming and outgoing radiative fluxes in the shortwave and thermal ranges (Kipp \& Zonen B.V., Delft, Netherlands). The lighter and less expensive CNR2 model, which measures net shortwave and net long wave radiative fluxes, replaced the Q7.1 at the cottonwood long-IFI site just weeks before a burned cottonwood crown toppled the tower. All radiometers were placed near the top of the tower to minimize shading effects.

\subsection{Flux Data Processing}

2.3.1. $Q A / Q C$. Prior to and following application of standard flux corrections, nonphysical observations were flagged for removal from analysis (e.g., relative humidity measurements of less than zero or products of overrotation). Out-of-range measurements were also discarded (e.g., $\left|Q_{E}\right|>1000$ ). Data from periods of low turbulence, particularly at night when the friction coefficient $\left(u^{*}\right)$ was less than $0.25 \mathrm{~m} \mathrm{~s}^{-1}$ [27], were retained but flagged for later analysis.

2.3.2. Turbulent Fluxes and Corrections. Vertical $Q_{E}$ and virtual heat flux $\left(Q_{H v}\right)$ were calculated as the 30 min covariance between $10 \mathrm{~Hz}$ measurements of deviations from mean of vertical wind speed $\left(w^{\prime}\right)$ and specific humidity $\left(q^{\prime}\right)$, or virtual (potential) temperature $\left(T_{v}\right)$, respectively [11]. Positive values were indicative of fluxes leaving the surface for $Q_{G}, Q_{H}$, and $Q_{E}$. $Q^{*}$ was positive when downward radiative fluxes were larger than upward fluxes (i.e., $Q^{*}$ was positive toward the surface).

$T_{v}$ is the temperature at which dry air has the same density as moist air, and it is always larger than the temperature of unsaturated moist air $(T)$. To obtain accurate measurements of $Q_{H}$ in moist air, $T_{v}$ or $Q_{H v}$ must be converted to $T$ or $Q_{H}$, respectively [28]. Because $10 \mathrm{~Hz}$ observations were not available from systems utilizing CR23X dataloggers, correction of $T_{v}^{\prime}$ was not practical. Using an independent 
measure of $T, Q_{H}$ was computed from $Q_{H v}$ following the Campbell Scientific, Inc., open path eddy covariance manual:

$$
Q_{H}=\left(\frac{\bar{T}}{T_{v}}\right)\left(Q_{H v}-\frac{0.51 \cdot C_{p} \cdot \rho_{m} \cdot \Re_{m} \cdot \bar{T}^{2}}{P \cdot \lambda}\right),
$$

where the overbars represent 30 min averages, $C_{p}\left[\mathrm{~J} \mathrm{~kg}^{-1} \mathrm{~K}^{-1}\right]$ is the specific heat capacity of moist air, $\rho_{m}\left[\mathrm{~kg} \mathrm{~m}^{-3}\right]$ is the density of moist air, $\mathfrak{R}_{m}\left[\mathrm{kPa} \mathrm{m}^{3} \mathrm{~K}^{-1} \mathrm{~kg}^{-1}\right]$ is the gas constant for moist air, and $\lambda\left[\mathrm{J} \mathrm{kg}^{-1}\right]$ is the latent heat of vaporization $\left(2.501-0.00237 T\left[{ }^{\circ} \mathrm{C}\right]\right)$. Each of $C_{p}, \rho_{m}$, and $\mathfrak{R}_{m}$ were determined from the associated constants for dry air: $C_{p}=C_{p d}(1+0.84 q), \rho_{m}=P /\left(\mathfrak{R}_{m} T\right)$, and $\mathfrak{R}_{m}=$ $\mathfrak{R}(1+0.608 q)$ where $C_{p d}=1004.67\left[\mathrm{~J} \mathrm{~kg}^{-1} \mathrm{~K}^{-1}\right]$ and $\mathfrak{R}=$ $0.287\left[\mathrm{kPa} \mathrm{m}^{3} \mathrm{~K}^{-1} \mathrm{~kg}^{-1}\right]$. Both $T$ and $T_{v}$ are in $[\mathrm{K}]$ except where otherwise noted, and $q$ is in $\left[\mathrm{g} \mathrm{g}^{-1}\right]$.

Corrections for top-of-canopy conditions were applied using the preceding constants for moist air. The first correction was performed for KH20 systems. The KH20 correction was a two-step process: (1) the oxygen correction to discount the absorption of oxygen by the krypton beam and (2) a second-order polynomial correction for the effect of atmospheric humidity on the calibration coefficient $k_{w}$. The remaining corrections were performed on data from all systems.

Two-dimensional rotation to natural wind coordinates was performed upon each $30 \mathrm{~min}$ observation to force stationarity in vertical wind speed (i.e., $\bar{w}=0$ ), in crosswind speed (i.e., $\bar{v}=0$ ), and in the covariance between streamwise and cross-stream wind speeds (i.e., $\overline{u^{\prime} v^{\prime}}=0$ ) [29]. Observations were considered overrotated and removed from analysis when $Q_{E}<-100$ or $Q_{H}<-300 \mathrm{~W} \mathrm{~m}^{-2}$. Frequency response corrections were performed using the spectral transfer function of Massman and Clement [30]. Atmospheric stability was determined as $\zeta=(z-d) / L$, where $z$ is the sensor height, $d$ is the zero plane displacement, $L$ is the Obukhov length, and $d$ is assumed to be two-thirds of the canopy height $h_{c}$ [31]. Data were then corrected for the effect of heat and water fluxes on atmospheric density measurements [32].

2.4. Energy Fluxes and ET. Cloud-free and gap-free days were identified for drought index comparisons to avoid the confounding effects of cloud properties on fluxes. Single representative 24 -hour periods were chosen in which $30 \mathrm{~min}$ observations of $Q^{*}, Q_{E}, Q_{H}$, and $Q_{G}$ were evaluated. In multiyear comparisons, dates were chosen that were within the same 7-10-day period, with a preference for the same day of the year when possible. Responses of $Q_{E}$ to $Q^{*}$, representing the evaporative fraction $(\mathrm{EF})$, were evaluated using $60 \mathrm{~min}$ average fluxes during and including all daytime observations between July 17 and August 16. Data gaps were not filled to avoid autocorrelation with model training data.

To compare ET amongst sites $Q_{E}$ was accumulated on each day that did not contain data gaps. Next, a higher-order polynomial was fit each year to daily ET, which averaged ET across intraseasonal variations and clusters of data gaps [11]. Total annual ET was determined as the cumulative fitted ET.

2.5. Hydroclimate and Statistical Analyses. The state of the hydroclimate, from extremely dry to extremely wet, was determined from the Palmer hydrologic drought index (PHDI, http://www.ncdc.noaa.gov). As these sites are located within GDEs, which obtain their water from snowmelt and rainfall in the upper catchments, both local (central valley New Mexico) and regional (central valley, central highlands, and northern mountains in New Mexico and the Colorado headwaters) PHDI values were used. PHDI represents an approximate balance between moisture supply (precipitation and run-on) and demand (ET and runoff). Neutral conditions are defined as $-2<$ PHDI $<2$. Moderately dry conditions are indicated at or below -2 ; they become severe drought at -3 , and extreme drought begins at PHDI values below -4 . Wet conditions are similarly scaled in positive values (moderately wet, very wet, and extremely wet). PHDI commonly varies between both extremes in semiarid environments (e.g., Figure 1).

Drought and wet conditions were compared during years when local or regional PHDI was at least moderate (Figure 1). Thus, these comparisons were performed in June 2001 (wet) and June 2003 (dry) (Table 2). All drought comparisons were made within one month of the summer solstice when $Q_{s}$ was maximal. The regressions between $Q_{E}$ and $Q^{*}(\mathrm{EF})$ and between $Q^{*}$ and $Q_{s}$ were compared across sites and climatic conditions using analysis of covariance (Matlab r2009, Mathworks, Natick, Massachusetts, USA). Analysis of variance was used to compare annual totals of ET amongst the four sites. A significance level of 0.05 was chosen for all statistical inferences.

\section{Results}

3.1. Water Budgets for the Four Sites. Annual rainfall ranged from 200 to $270 \mathrm{~mm} \mathrm{y}^{-1}$ across all four sites (Figure 2). Mean ecosystem ET was much larger than average rainfall (by a factor of 2.5 to 6) across all four sites and in all years. Mean annual ecosystem ET was significantly smaller in the saltcedar long-IFI forest than the saltcedar short-IFI and cottonwood long-IFI forests ( site $F=24.7$; $\mathrm{df}=7$ and $40 ; p<$ 0.0001 ; Figure 2). The small number of years that the tower operated in the cottonwood short-IFI forest (Table 1) reduced the statistical power of the comparison; thus mean annual ET of the cottonwood short-IFI site was not statistically different from any of the other three sites (Figure 2).

Monthly ET was large at mid-year, reaching between 100 and $300 \mathrm{~mm} \mathrm{month}^{-1}$ (Figure 3) and often exceeded annual rainfall at some sites (e.g., the saltcedar short-IFI site; Figure 3). However, differences in mean annual ET across all years (Figure 2) were reflected in differences amongst the peak values of monthly ET across the four sites (Figure 3). Amongst the cottonwood forests, peak monthly ET varied more across years at the short-IFI site than in the forest with a long IFI (Figure 3). At the cottonwood long-IFI site, ET during the growing season was constant or slightly declining until 2007, after the fire on June 16, 2006, that reduced 
TABLE 2: Surface conditions on representative cloud-free days.

\begin{tabular}{|c|c|c|c|c|c|c|c|}
\hline Condition & Site & Date & $\mathrm{PHDI}^{\mathrm{a}}$ & $\beta^{\mathrm{b}}$ & $\mathrm{DGW}^{\mathrm{c}}(\mathrm{cm})$ & $\Theta_{m}{ }^{\mathrm{d}}$ & $\mathrm{ET}(\mathrm{mm})$ \\
\hline Wet & CW-long-IFI & 03-Jun-01 & 3.44 & -0.36 & 146 & n.o. & 7.2 \\
\hline Dry & CW-long-IFI & 06-Jun-03 & -1.34 & 0.08 & 170 & 0.23 & 6.8 \\
\hline Wet & CW-short-IFI & 05-Jun-01 & 3.44 & -0.26 & 89 & n.o. & 7.1 \\
\hline Dry & CW-short-IFI & 14-Jun-03 & -1.34 & -0.28 & 140 & 0.30 & 6.2 \\
\hline Wet & SC-long-IFI & 04-Jun-01 & 3.44 & 0.51 & 190 & n.o. & 4.4 \\
\hline Dry & SC-long-IFI & 12-Jun-03 & -1.34 & 0.71 & 210 & 0.05 & 4.3 \\
\hline Wet & SC-short-IFI & 02-Jun-01 & 3.44 & -0.10 & 187 & n.o. & 8.5 \\
\hline Dry & SC-short-IFI & 10-Jun-03 & -1.34 & 0.27 & 180 & 0.07 & 7.3 \\
\hline Flooded & SC-short-IFI & 07-Jun-05 & 5.84 & 0.18 & -53 & 0.57 & 9.1 \\
\hline
\end{tabular}

${ }^{\mathrm{a}} 0=$ normal, $-2=$ moderate drought, $3=$ very wet.

${ }^{\mathrm{b}} \beta$ : daily average.

${ }^{c}$ Negative values represent flood water depth.

${ }^{\mathrm{d}}$ Measured at the surface $(0-10 \mathrm{~cm})$.

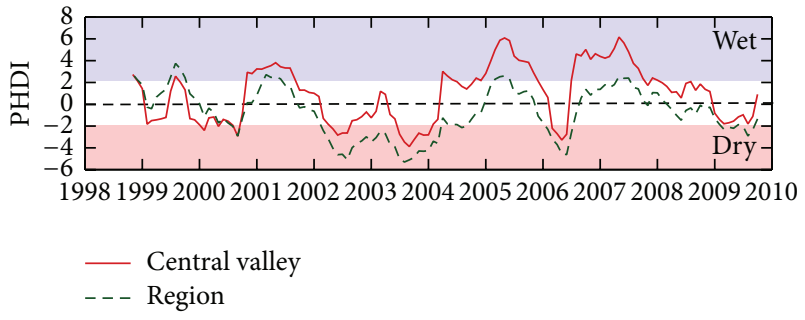

FIGURE 1: Monthly Palmer hydrologic drought index (PHDI) values averaged across the study area (central valley, solid line) and averaged across the central valley and upstream catchment (region, broken line).

the surface area of green, transpiring leaves. By contrast, monthly ET increased annually between 2003 and 2008 at both saltcedar sites, although that trend reversed in 2009 (Figure 3).

The maximum of daily ET was $9.5 \mathrm{~mm} \mathrm{~d}^{-1}$ in cottonwood forests and $12.5 \mathrm{~mm} \mathrm{~d}^{-1}$ at saltcedar-dominated sites. ET from the cottonwood short-IFI forest was substantially smaller than in the cottonwood long-IFI forest in three out of the four years that measurements overlapped (2000, 2002, and 2003), although individual days occurred in which large ET fluxes were released from the cottonwood short-IFI forest $\left(>9 \mathrm{~mm} \mathrm{~d}^{-1}\right.$, Figure 3$)$.

3.2. Radiation: Solar and $Q^{*}$. At all sites, $Q^{*}$ was strongly related to solar radiation $\left(Q_{s}\right)$ (Table 3 ). With only one exception, all slopes and intercepts of the relationship between $Q^{*}$ and $Q_{s}$ were significantly different from the global values $\left(\right.$ site $\times Q_{s} ; F=8297 ; \mathrm{df}=11$ and 125,$\left.175 ; p<0.0001\right)$. These slopes were larger in short-IFI sites ( 0.80 to 0.83$)$ than long ( 0.73 to 0.79 ) (Table 3 ). Daily peak $Q^{*}$ at all sites was between 700 and $800 \mathrm{~W} \mathrm{~m}^{-2}$, with little interannual variation in peak $Q^{*}$ regardless of drought or flood condition (Figures 4 and 5).

When averaged across all years, total daily $Q^{*}$ was largest in the summer and smallest in the winter (Figure 6). Maximal annual $Q^{*}$ exceeded $20 \mathrm{MJ} \mathrm{m}^{-2}$ day $^{-1}$ at two sites: saltcedar

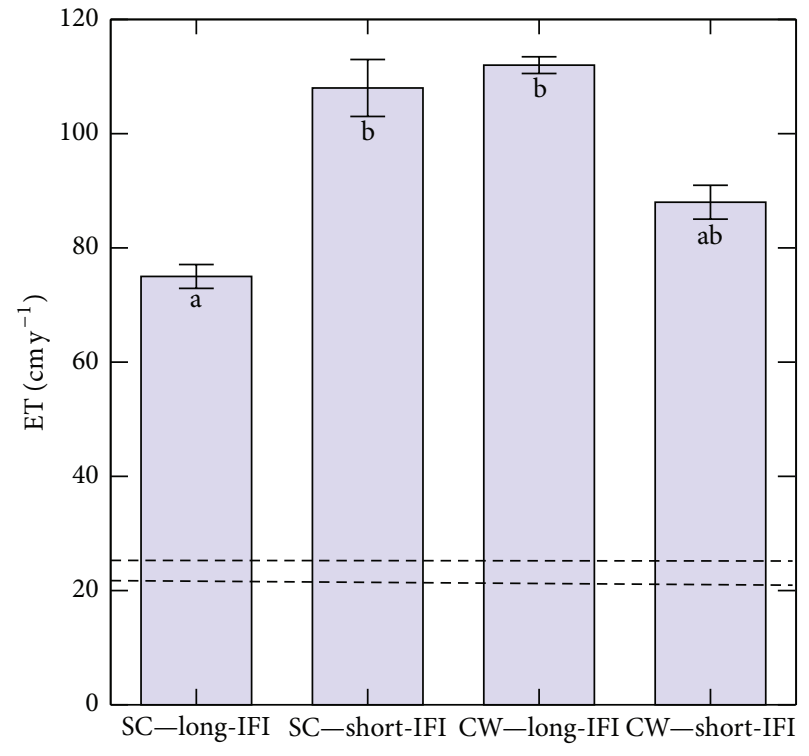

FIGURE 2: Annual evapotranspiration $(E T) \pm$ standard error. Values with the same letter are not significantly different $(p<0.05)$. The two horizontal dashed lines represent the range in annual average rainfall in the central valley of the Middle Rio Grande [3].

short-IFI $\left(20.3 \mathrm{MJ} \mathrm{m}^{-2} \mathrm{~d}^{-1}\right)$ and cottonwood short-IFI $\left(20.2 \mathrm{MJ} \mathrm{m}^{-2} \mathrm{~d}^{-1}\right.$; Figure 6). During winter (NovemberFebruary), $Q^{*}$ was typically low but highly variable at all sites (Figure 6). At the cottonwood long-IFI site, winter $Q^{*}$ was large (up to $16.6 \mathrm{MJ} \mathrm{m}^{-2} \mathrm{~d}^{-1}$ ) and highly variable (Figure 6).

3.3. Convection: Turbulent Latent and Sensible Heat Fluxes. The magnitude of $Q_{E}$ exceeded $Q_{H}(-1<\beta<1)$ at all sites (Table 2). Evaporative cooling, indicated when $Q_{H}$ was directed toward the surface (i.e., $\beta<0$ ), was common in these riparian GDEs during extremely wet periods, except at the saltcedar long-IFI site where $\beta$ was 0.5 (Table 2). As these riparian sites dried, $\beta$ increased except at the short-IFI site dominated by cottonwood, where $\beta$ remained negative (Table 2). At the cottonwood (dry) and saltcedar short-IFI 


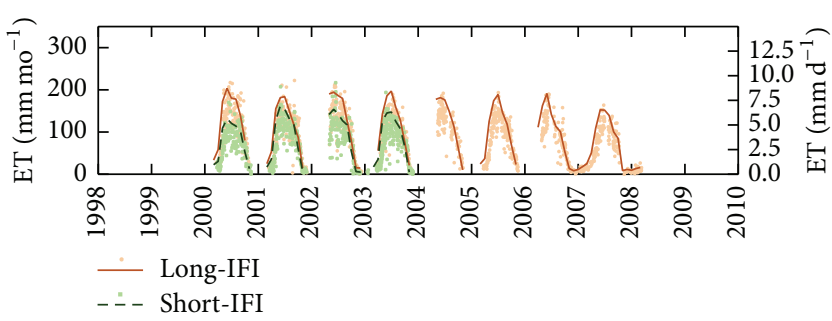

(a) Cottonwood

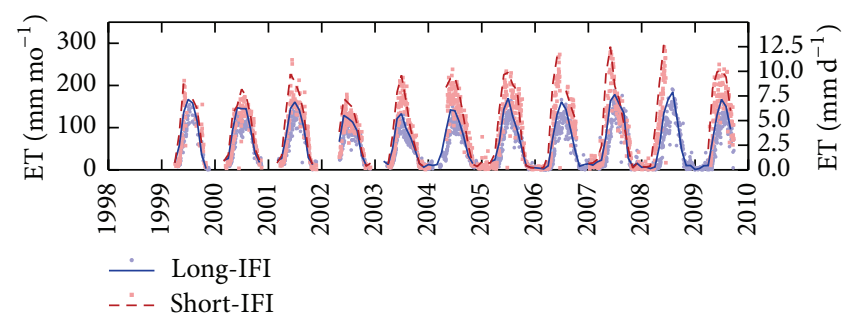

(b) Saltcedar

Figure 3: Total monthly (lines) and daily (symbols) ET at cottonwood (a) and saltcedar (b) sites. Long IFI is indicated by the solid line and small circles. Sites with a short IFI are indicated by the broken line and small squares. The first day of each year is indicated along the $x$-axis.

TABLE 3: Least squares regression model coefficients between $30 \mathrm{~min}$ observations of solar $\left(Q_{s}\right)$ and net radiation $\left(Q^{*}\right), Q^{*}=m Q_{s}+b$. Slopes $(m)$ marked by an asterisk are not significantly different $(p<$ $0.05)$.

\begin{tabular}{llcccc}
\hline Site & Date range $^{\mathrm{a}}$ & $r^{2}$ & $m$ & $b$ & $\alpha^{\mathrm{b}}$ \\
\hline CW-long- & $\begin{array}{l}\text { 26-Apr-30-Sep- } \\
\text { IFI }\end{array}$ & 0.990 & $0.728^{*}$ & -76.6 & n.o. \\
& $\begin{array}{l}\text { 1-May-31-Dec- } \\
\text { 2007 }\end{array}$ & 0.991 & $0.726^{*}$ & -48.3 & n.o. \\
\hline \multirow{2}{*}{ SC-long- } & 1-May-30-Sep- & 0.992 & 0.770 & -37.0 & n.o. \\
IFI & 2006 & 0.989 & 0.766 & -48.8 & n.o. \\
& 2008 & 0.985 & 0.789 & -63.5 & 0.11 \\
& 1-Jan-24-Sep-2009 & 0.988 & 0.796 & -63.9 & 0.10 \\
\hline SC-short- & 2007 & 0.993 & 0.832 & -44.7 & n.o. \\
IFI & 9-Apr-24-Sep- & 0.990 & 0.823 & -57.4 & 0.12 \\
& 2009 & & & & \\
\hline
\end{tabular}

${ }^{\mathrm{a}}$ Single year range: the entire year's data collection fit the same line.

${ }^{\mathrm{b}} \alpha$ : midday (10.00-14.00 LST) average albedo. n.o.: no observations.

${ }^{c}$ Data from 15-June-2006 to 18-June-2006 removed following fire; postfire $Q_{\min }^{*}=-321 \mathrm{Wm}^{-2}$.

(wet) sites, positive $Q_{H}$ at midday balanced negative $Q_{H}$ during the evening and early nighttime $(\beta=0.08$ and -0.1 , resp.; Table 2$)$. In contrast, average daily $Q_{H}$ was positive at the saltcedar short-IFI site $(\beta=0.27$ and 0.18 in dry and flooded conditions, resp.; Table 2).

Large positive $Q_{H}$ occurred at midday in the cottonwood long-IFI (dry), saltcedar long-IFI (wet and dry), and saltcedar short-IFI (dry and flooded) sites (Figures 4 and 5). Peak $Q_{E}$ was lower during drought than during wet conditions at short-IFI sites, whether dominated by cottonwood or saltcedar (Table 2, Figure 4). At the cottonwood and saltcedar long-IFI sites, $Q_{E}$ was the same during drought and wet conditions and was equal to or lower than $Q_{E}$ at the companion short-IFI site during wet conditions (Figure 4). At the saltcedar long-IFI site, $Q_{E}$ and $Q_{H}$ were nearly equal at each about $50 \%$ of $Q^{*}$ (Figure 4 ). When averaged across years, growing season $Q_{H}$ was negative at both cottonwood sites and at the saltcedar short-IFI site during springtime (Figure 6). Over the course of the year, $Q_{E}$ was balanced by $Q_{H}$ : increases in $Q_{E}$ were reflected by decreases in $Q_{H}$ (Figure 5). The saltcedar short-IFI site began the growing seasons as a strong
$Q_{H}$ sink (i.e., $Q_{H}<0$ ) but was at near neutral thermal stratification (i.e., $Q_{H} \approx 0$ ) by August (Figure 5). Despite failing to account for canopy storage and inverted fluxes (e.g., $Q_{H}<0$ ), net energy balance (i.e., $\left\{Q_{H}+Q_{E}\right\} /\left\{Q^{*}-Q_{G}\right\}$ ) was $78 \%$ in the saltcedar ecosystems and $64 \%$ in the cottonwood long-IFI forest.

Daily $Q_{E}$ was closest to $Q^{*}$ at the saltcedar short-IFI site (Figure 6). Figure 7 illustrates conversion of $Q^{*}$ into $Q_{E}$ at each of the sites during drought and wet conditions. The slope of the $Q^{*}$ versus $Q_{E}$ relationship represents the average evaporative fraction (EF). Significant differences in EF were found across sites and conditions (site $\times$ condition $\times Q^{*}$; $F=72.45 ; \mathrm{df}=11$ and 3,$752 ; p<0.0001)$. EF was significantly smaller during drought than wet conditions except at the cottonwood long-IFI site (Table 4). The saltcedar short-IFI site had the largest EF during wet conditions (Table 4).

3.4. Conduction: $Q_{G}$ and Flood Water Heat Flux. Negligible $Q_{G}$ was observed at the saltcedar short-IFI site under dry conditions (Figure 4 ). Instantaneous $Q_{G}$ at all of the remaining sites in the drought comparison were small but nonnegligible (Figure 4). Small $Q_{G}$ fluxes were observed under the shade of groundwater-dependent vegetation at all four sites. No relationships were identified between $Q_{G}$ and depth-to-groundwater (DGW) or $\Theta_{g}$ (Table 2).

Except when the site was flooded, $Q_{G}$ followed a similar pattern at all sites: $Q_{G}$ was negligible at night, directed into the soil (i.e., positive $Q_{G}$ ) predominantly in the afternoon and early evening, and then back out of the soil in the morning (Figure 4). The presence of floodwater had its largest effect on $Q_{G}$, which showed its largest range under flooded conditions (Figure 5). When floodwaters were present, $Q_{G}$ was shifted to positive values from midnight to noon and negative for the remainder of the day. Although the magnitude of heat fluxes through floodwater was larger than through dry soil, daily average $Q_{G}$ was negligible at all sites and across all seasons (Figure 6).

3.5. Impacts of Flooding on Ecohydrology and Forest WaterUse. Peak midday $Q^{*}$ was slightly larger during inundation than noninundated times. At the flooded saltcedar site, $Q^{*}$ peaked at $845 \mathrm{~W} \mathrm{~m}^{-2}$ (Figure 5), and this value was the largest observed in the Middle Rio Grande. Heat storage in the soil surface and water column contributed to a daily range in 


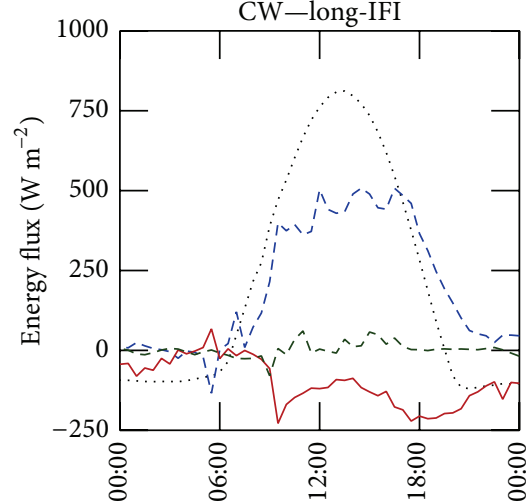

(a) Wet

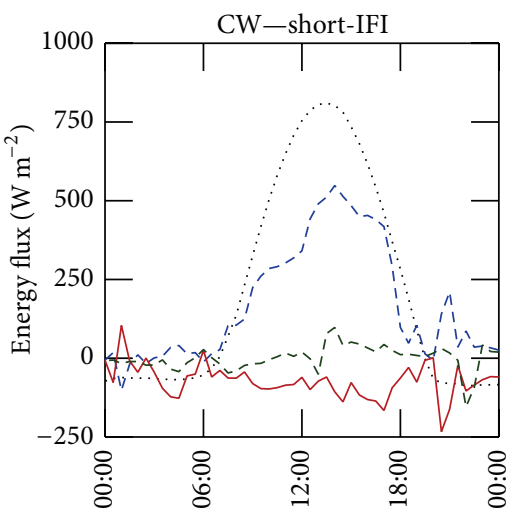

(d) Dry

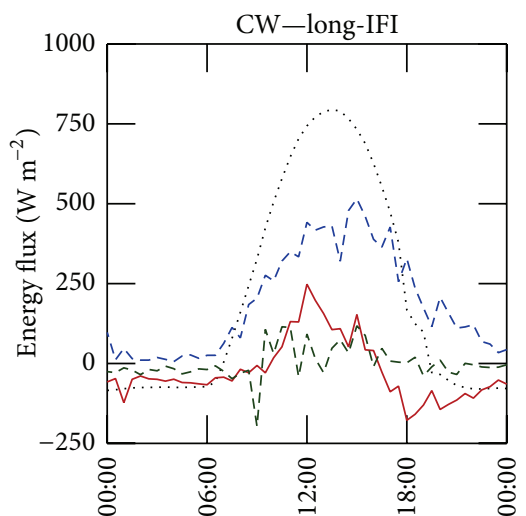

(b) Dry

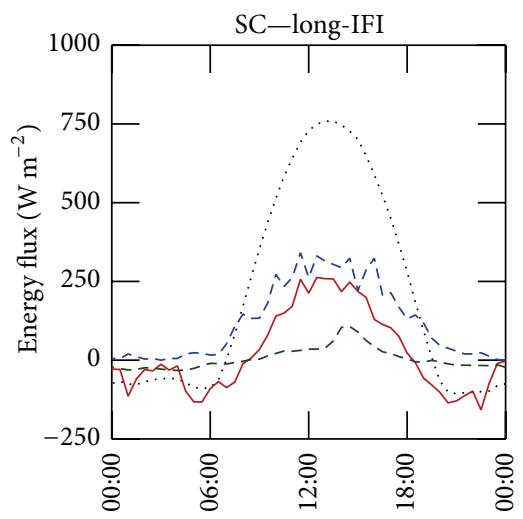

(e) Wet

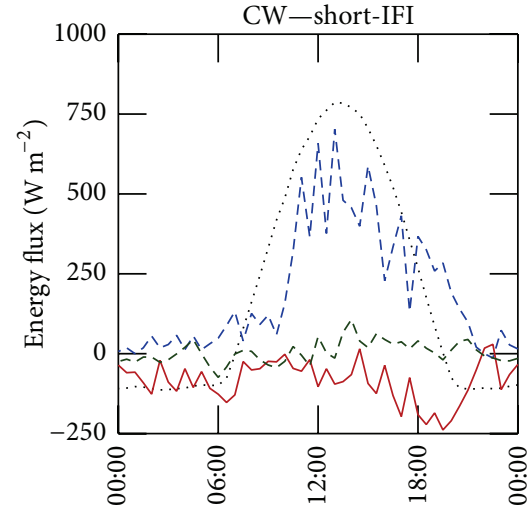

(c) Wet

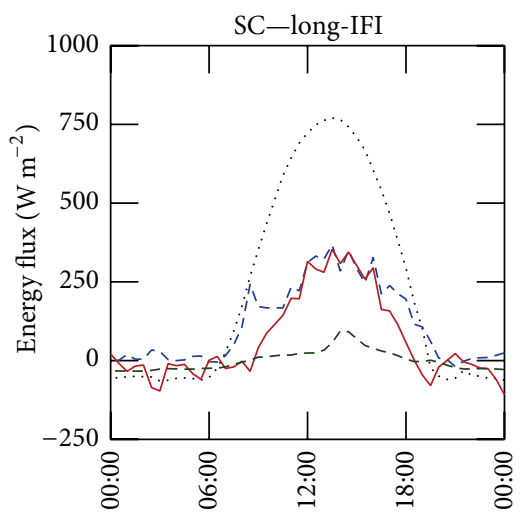

(f) Dry

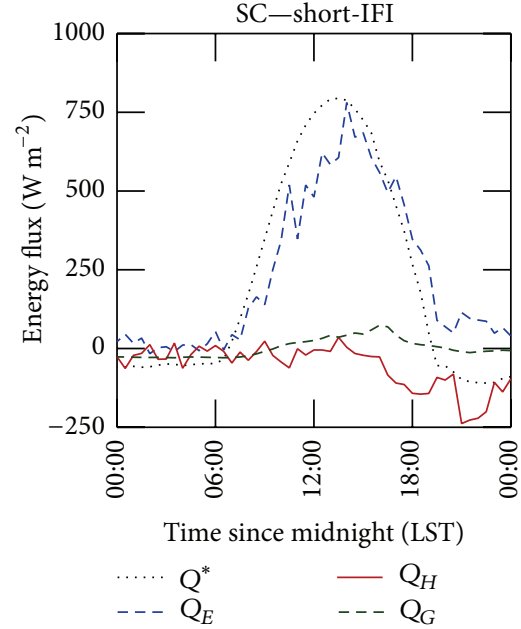

(g) Wet

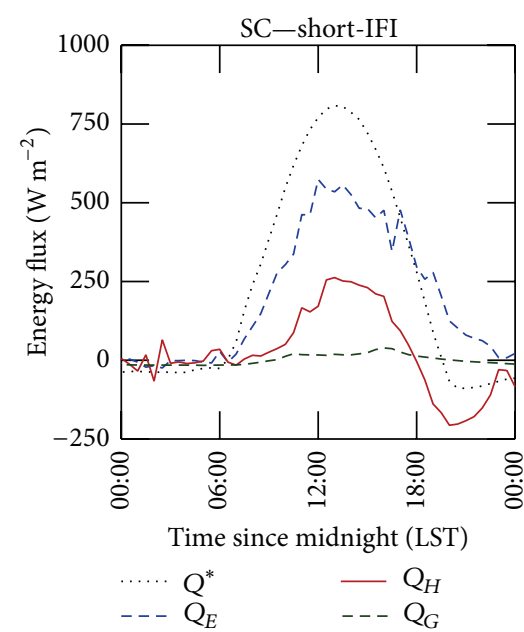

(h) Dry

Figure 4: Half-hourly average energy fluxes at the four sites (Table 1) under clear sky conditions and wet versus dry conditions (Table 2). Energy fluxes are net radiation $\left(Q^{*}\right.$, dotted line), latent heat flux $\left(Q_{E}\right.$, blue dashed line), sensible heat flux $\left(Q_{H}\right.$, red solid line), and ground heat flux $\left(Q_{G}\right.$, green dashed line). CW: cottonwood; SC: saltcedar; IFI: interflood interval.

instantaneous rates of $Q_{G}$ of -110 to $86 \mathrm{~W} \mathrm{~m}^{-2}$ at the flooded saltcedar site (Figure 5). Nocturnal $Q_{E}$ was larger during flooding than when the saltcedar short-IFI site was wet or dry (Figures 4 and 5). Total daily $Q_{E}(\mathrm{ET})$ at the saltcedar site was larger when flooded $\left(9.1 \mathrm{~mm} \mathrm{~d}^{-1}\right)$ than when wet but not inundated (8.5 $\mathrm{mm} \mathrm{d}^{-1}$, Table 2).

\section{Discussion}

4.1. Characteristics of GDEs: ET and Management. Riparian ecosystems in semiarid regions are sites of large rates of primary production and ET, in contrast to nonriparian, semiarid ecosystems $[33,34]$, reflecting the influence of an additional 
TABLE 4: Analysis of covariance comparing evaporative fraction between sites and drought condition. None of the intercepts \pm standard error are significantly different $(p<0.05)$ from the single line intercept $(59.4 \pm 2.4)$. Slopes \pm s.e. with the same letter are not significantly different.

\begin{tabular}{lcccc}
\hline Condition & Site & $r^{2}$ & Intercept & Slope \\
\hline Wet & CW-long-IFI & 0.60 & $56.0 \pm 7.3$ & $0.515^{\mathrm{ab}} \pm 0.014$ \\
Dry & CW-long-IFI & 0.72 & $50.4 \pm 7.6$ & $0.543^{\mathrm{bc}} \pm 0.015$ \\
\hline Wet & CW-short-IFI & 0.69 & $47.3 \pm 7.2$ & $0.478^{\mathrm{ac}} \pm 0.016$ \\
Dry & CW-short-IFI & 0.66 & $74.1 \pm 7.9$ & $0.381^{\mathrm{d}} \pm 0.016$ \\
\hline Wet & SC-long-IFI & 0.80 & $70.3 \pm 8.5$ & $0.449^{\mathrm{ad}} \pm 0.018$ \\
Dry & SC-long-IFI & 0.66 & $64.1 \pm 7.7$ & $0.280^{\mathrm{f}} \pm 0.016$ \\
\hline Wet & SC-short-IFI & 0.76 & $54.1 \pm 7.5$ & $0.679^{\mathrm{e}} \pm 0.016$ \\
Dry & SC-short-IFI & 0.82 & $60.2 \pm 7.5$ & $0.581^{\mathrm{b}} \pm 0.015$ \\
\hline
\end{tabular}

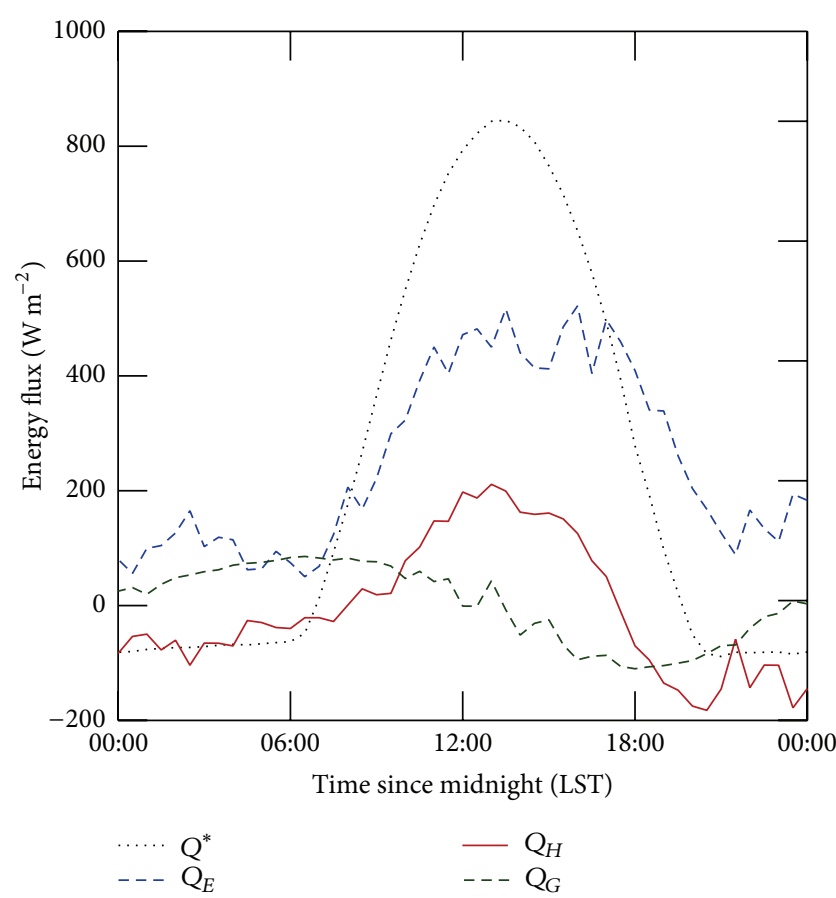

FIGURE 5: Half-hourly average energy fluxes at the inundated saltcedar site (SC-short IFI).

source of water on the ability to fix carbon. However, identification of groundwater-dependent ecosystems (GDEs) in the field is not trivial and typically requires an understanding of the ecohydrology of groundwater-dependent vegetation [35]. One of the key characteristics of GDEs is that ET consistently exceeds annual average precipitation [36]. In the present study, ET from both types of GDEs (cottonwood and saltcedar) was three to six times larger than the annual average precipitation of 200-250 mm (Figure 2), indicating that both types of forests were groundwater-dependent.

We found large differences in ET between the two forest types and flooding regimes, supporting our first hypothesis. Interestingly, ET in the two forest types did not respond to flooding regime in the same way: ET was larger in the saltcedar site with a short IFI, whereas ET tended to be larger in the cottonwood site with a long IFI. There are two explanations for these divergent responses: (1) saltcedar abundance is favoured by deep groundwater and intermittent flooding [37], while (2) cottonwood ET can be limited by hypoxia and restricted rooting volume during flooding [11]. There are important implications of this finding related to the management of nonnative vegetation for the purposes of water salvage [38]. First, the choice of restoration site for management of nonnative vegetation can be informed by observations of the energy budget, particularly to identify evaporative cooling. Saltcedar sites undergoing evaporative cooling are likely to also have ET rates near the theoretical maximum $\left(12.5 \mathrm{~mm} \mathrm{~d}^{-1}\right)$, which make these forests a priority candidate for management [39]. Second, evaporative cooling can be maintained through management of native cottonwood forests, and this provides an important ecosystem service in populated areas. For example, conversion of saltcedar capable of large ET rates to sparse cottonwood with an understory of upland vegetation can contribute to reduced ET $[38,40]$, while maintaining evaporative cooling on a small scale, regardless of climatic conditions.

Water management in the Rio Grande depends upon knowledge of the patterns of ET in the vegetation of riparian GDEs. Cottonwood trees can maintain maximal ET rates if depth-to-groundwater does not exceed about three metres [41]. As long as water supply to the Middle Rio Grande can maintain the riparian aquifer and barring burning of the forests, cottonwood forests will continue to support large daily and monthly rates of ET (Figure 3). By contrast, the hydraulic architecture of saltcedar is highly resistant to drought stress [42]. This promotes survival through dry years, albeit with smaller ET rates, but with increasing ET during subsequent wet years (Figure 3 ). However, groundwater resources are expected to decline with declining regional snowpack; thus the preferential survival of saltcedar could result in continued strain on the water budget, while native trees would tend to die back due to hydraulic failure [43-45]. The magnitude of ET from saltcedar and its effect on the water budget depend upon the pattern of water supply (drought to deluge) and distribution of short-IFI and long-IFI sites [3]. ET from saltcedar can equal or exceed available energy [46], or ET can equal half of that [19]. Regardless, saltcedar has a more detrimental effect on water budgets than the native xeric vegetation that dominated the Middle Rio Grande riparian corridor over a century ago, before nonnative species invaded and when cottonwood trees were far less prevalent $[21,38]$.

4.2. Evaporative Cooling. Rates of midday net radiation flux $\left(Q^{*}\right)$ observed in the present study $\left(750-825 \mathrm{~W} \mathrm{~m}^{-2}\right)$ represent some of the largest rates published for vegetated land surfaces (cf. $[1,10,14,47-50])$. This is partially attributed to the fact that semiarid regions have a preponderance of cloud-free days. Furthermore, our study sites were located in a region with moderate to large radiation and a high temperature regime, which favours large rates of $Q^{*}$. However, the groundwater dependency evident for all four sites also contributes to these large values of $Q^{*}$ because of the reduction of radiative cooling that occurs so frequently for 


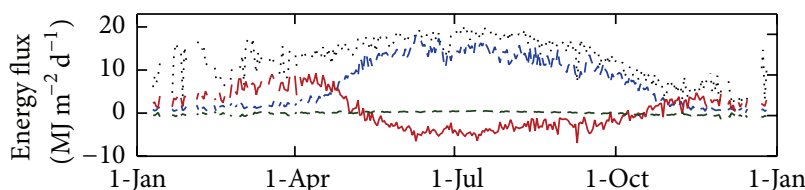

(a) CW-long-IFI

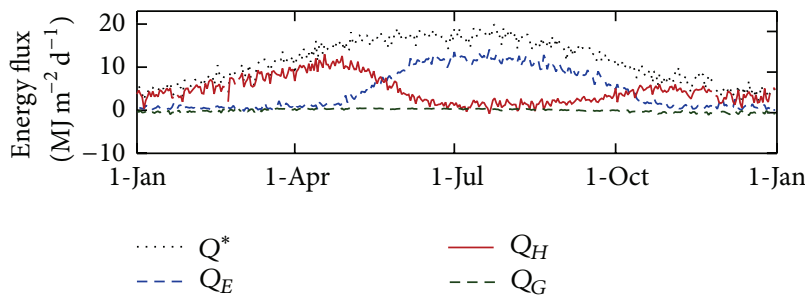

(c) SC-long-IFI

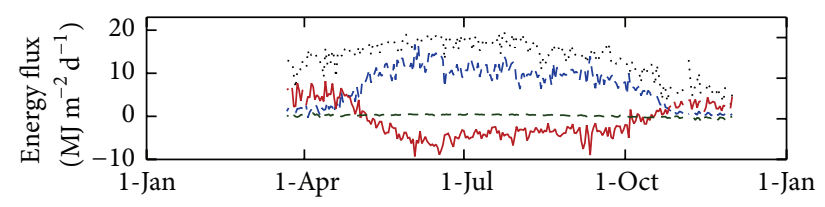

(b) CW-short-IFI

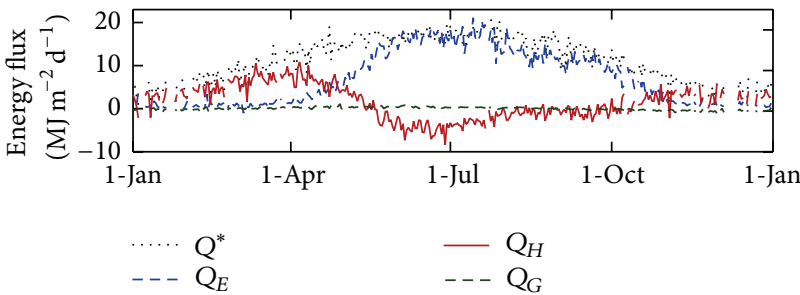

(d) SC-short-IFI

Figure 6: Daily total energy fluxes, averaged across all years.

vegetation accessing groundwater on a daily basis. Another characteristic of GDEs is that energy partitioning results in a Bowen ratio that is higher than -1 but less than zero [2]. Thus, we conclude that patterns of ecosystem energy fluxes can be used to differentiate between adjacent GDE and nonGDE systems.

With abundant available moisture and sunlight, evaporative cooling of GDE canopies can dominate the energy balance [4, 51-54], consistent with our second hypothesis. The relatively large cottonwood leaves are most likely to establish counter-gradient fluxes of large $Q_{E}$ and negative $Q_{H}$ during daytime hours (i.e., evaporative cooling; Figure 4), although $Q_{H}$ can be a source of available energy in three of the four GDE sites (the exception being the driest saltcedar site, Figure 4). Because of the coupling between $Q_{E}$ and $Q_{H}$ in riparian GDEs, evaporative cooling facilitates remote and energy balance-based methodologies to estimate ET $[3,46,55]$. Estimates of ET are urgently required to select sites best suited for restoration and to choose the species composition that will attain the goal of minimizing ET and thereby enhancing water availability in-stream $[38,39]$ as a matter of securing water resources in the region, which is discussed in detail in the following section.

As leaf temperature and leaf water potential tend to be lower in Tamarix than cooccurring native species [56], evaporative cooling at the saltcedar short-IFI site represents cooling of the within-canopy air spaces rather than cooling of individual leaves. Evaporative cooling was restricted in the morning and early afternoon at the cottonwood long-IFI and saltcedar short-IFI sites when exposed to drought (Figure 4), although there was no corresponding decrease in ET in the cottonwood forest. Evaporative cooling was maintained at the cottonwood long-IFI site even though $Q_{E}$ and ET declined during drought (Table 2 and Figure 4), implying that (i) understory development below the cottonwood canopy was restricted during drought and therefore did not contribute to ET or (ii) cottonwood transpiration during a wet year exceeded the rates required to cool the canopy. Because the latter is unlikely given the year-round proximity of groundwater at both cottonwood sites, the drought-related decline in ET at the cottonwood short-IFI site was most likely the effect of understory dormancy during drought.

4.3. Hydroclimate and Water Security. Historically, cycles of drought and flooding had a large and recurrent effect on riparian vegetation structure and hydrology. With only one exception (cottonwood long-IFI), EF was lower during drought (Figure 7). Reduced EF indicates that the importance of $Q_{H}$ increased relative to $Q_{E}$ in response to drought, as predicted by our third hypothesis, and signified an increase in vegetation stress as ET became insufficient to moderate leaf or canopy temperature (Table 1). In saltcedar forests, seasonal average ET and LAI are strongly coupled to vapour pressure deficit (VPD; [11]), even though saltcedar extracts groundwater from depths of more than $10 \mathrm{~m}$ to $25 \mathrm{~m}$ to avoid moisture stress. In the present study, drought had a substantial effect on ET only at the saltcedar short-IFI site (Figure 3). In contrast, the proximity of groundwater at the cottonwood sites greatly ameliorated the impact of drought and consequently high ET was maintained throughout extreme drought.

Drought has very important impacts on energy and water budgets; thus drought can detrimentally impact the security of water resources, depending upon vegetation and land use responses to drought $[57,58]$. Extended droughts (megadroughts) recur regularly on a 20-70-year cycle throughout southwestern North America due to the climatic influences of the Pacific decadal oscillation (PDO) and Atlantic multidecadal oscillation (AMO) [59] and at their extremes have resulted in violent conflict (e.g., expulsion of the Spanish by the indigenous Pueblo people during the megadrought of the 1680s; [21]). Current law requires the delivery of a proportional amount of annual streamflow as in-stream deliveries between Colorado, USA, New Mexico, USA, Texas, USA, and Chihuahua, Mexico [17]. Meeting these compact and treaty obligations under current and future hydroclimate might require careful management of native and nonnative vegetation to minimize $\mathrm{EF}$ and vegetation density at the expense of reducing evaporative cooling. 


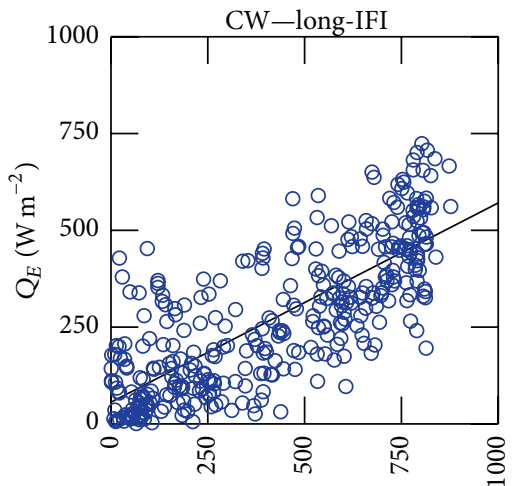

(a) Wet

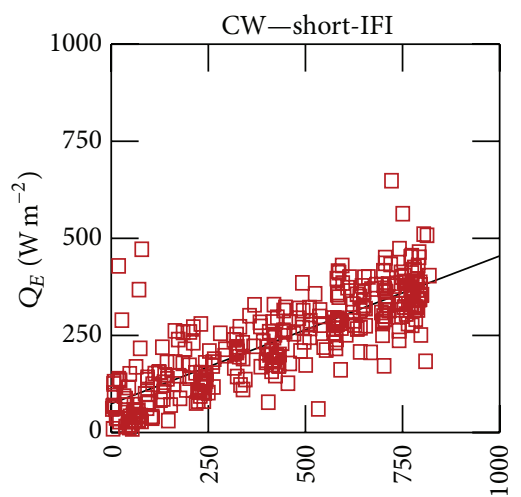

(d) Dry

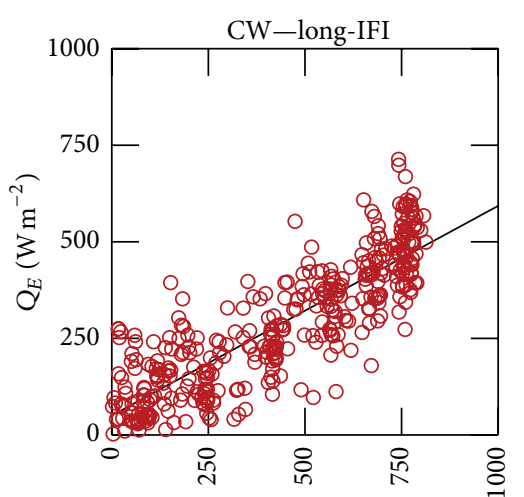

(b) Dry

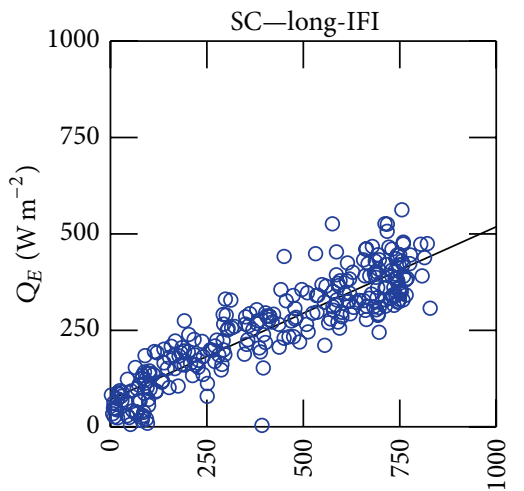

(e) Wet

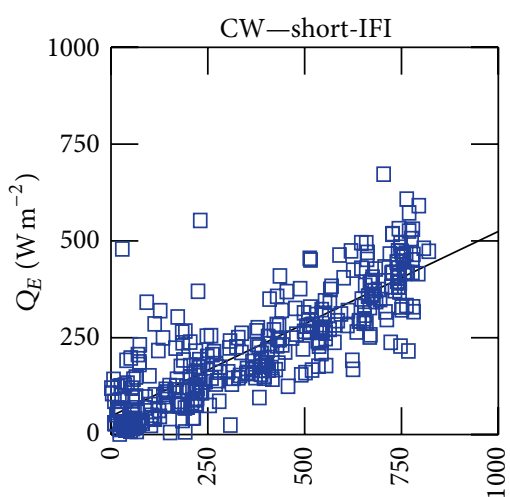

(c) Wet

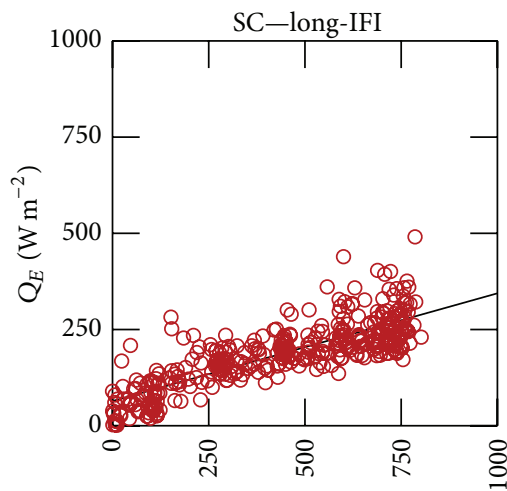

(f) Dry

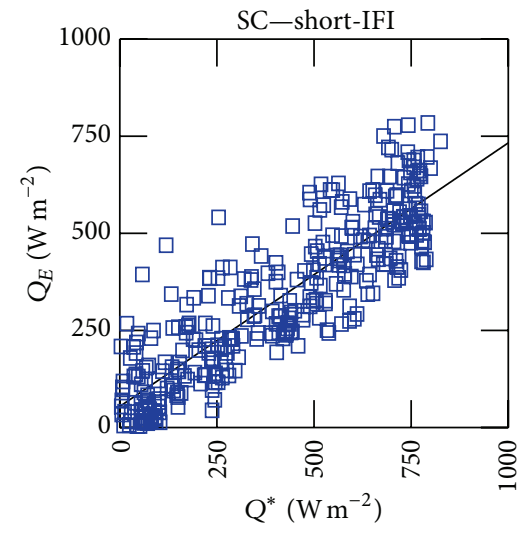

(g) Wet

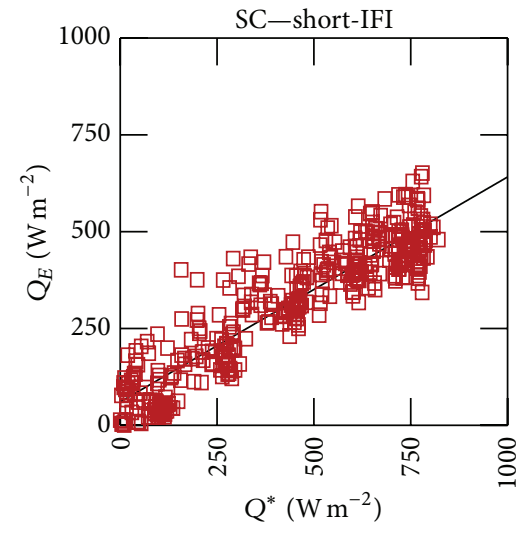

(h) Dry

FIGURE 7: Evaporative fraction and the linear relationships between latent heat flux $\left(Q_{E}\right)$ and net radiation $\left(Q^{*}\right)$.

Lastly, we predicted that $Q_{G}$ would be negligible except under flooded conditions. Indeed, $Q_{G}$ was negligible on a daily average under all conditions, including flooding, and tended to be small on a diel basis, except under flooding. Flooding resulted in increased evaporation and vegetation stress such that $Q_{H}, Q_{G}$, and nightly $Q_{E}$ were increased but daytime $Q_{E}$ was reduced (Figure 5). The amount of energy absorbed by floodwater (i.e., the magnitude of $Q_{G}$ ) in the saltcedar forest was similar to bare soil (data not shown) because leaf-out was delayed and the amount of radiation intercepted by the canopy was minimized. The combination of delayed leaf-burst, reduced transpiration and growth of adventitious roots contributed to avoiding flooding stress in saltcedar at these sites. In contrast, cottonwood had achieved full LAI development during spring flooding, thereby suppressing evaporation from the floodwaters by intercepting a larger fraction of $Q_{s}$ [11]. The effects of flooding on the water budget of saltcedar were short-lived because physiological 
and ET responses of saltcedar to drought were temporary, whilst ET continued to follow a 4-5-year increasing trend [39].

\section{Conclusions}

GDEs in semiarid regions are characterised by abundant access to sunlight and water and are distributed as ribbons of enhanced water and energy fluxes. We found that sites dominated by cottonwood or saltcedar exhibited rates of ET that exceeded rainfall by $250 \%$ to $600 \%$, strongly supporting the conclusion that these sites were groundwater-dependent. Differences in ET amongst cottonwood and saltcedar forests were related to patterns of energy fluxes (e.g., the efficiency of the conversion of $Q^{*}$ to $Q_{E}, E F$ ) induced by differences in flooding regime and vegetation stress responses to atmospheric VPD. Consequently, the hydrology of riparian GDEs depends upon the feedback between water and energy fluxes in combination with the spatial distribution of native and nonnative groundwater-dependent vegetation.

Controlling the expansion of high water-using saltcedar forests is key for management of water resources and for maintaining small refugia for parklands of sparse cottonwood and an understory of xeric shrubs and grasses. In this way, the benefits of evaporative cooling can be partially decoupled from an excessive load on the water budget. Excessive ET, especially at the higher end, impacts energy exchange through evaporative cooling, which is diagnosed when the Bowen ratio (i.e., ratio of sensible and latent heat fluxes, $Q_{H} / Q_{E}$ ) is between negative one and zero (i.e., $-1<\beta<0$ ). Evaporative cooling of the canopy alleviates stress due to high air temperature (1) through direct reduction of leaf temperature in cottonwood or (2) indirectly through reduction of canopy air temperature in saltcedar, which is microphyllous (i.e., has small leaves) such that each individual leaf has a negligible boundary layer and is thus in thermal equilibrium with canopy airspaces. Low leaf temperature limits radiative cooling, which contributes to particularly high values of net radiation $\left(Q^{*}\right)$.

Patterns of energy fluxes amongst GDEs provided a valuable diagnostic tool for evaluating ecosystem stress and hydrological processes. With only one exception, imposition of hydrologic drought reduced evaporative fraction (EF) in these sites (Table 4). With the shallow water tables of the northern and central Middle Rio Grande, native cottonwood maintained high ET and canopy cooling, thereby avoiding imposition of atmospheric heat stress. In the nonnative vegetation (saltcedar), no midday reduction in latent heat flux $\left(Q_{E}\right)$ was observed during drought, whilst reductions of ET and evaporative cooling were temporary, which minimised differences in the water budget between the native and nonnative riparian forests over the long term (Figure 2). Likewise, flooding had large but transient effects on water and energy fluxes. Flooding caused reduced transpiration and shutdown of evaporative cooling and increased evaporation.

\section{Symbols and Abbreviations}

$\mathfrak{R}_{m}$ : Gas constant for moist air $\left[\mathrm{kPa} \mathrm{kg}^{-1} \mathrm{~K}^{-1}\right]$

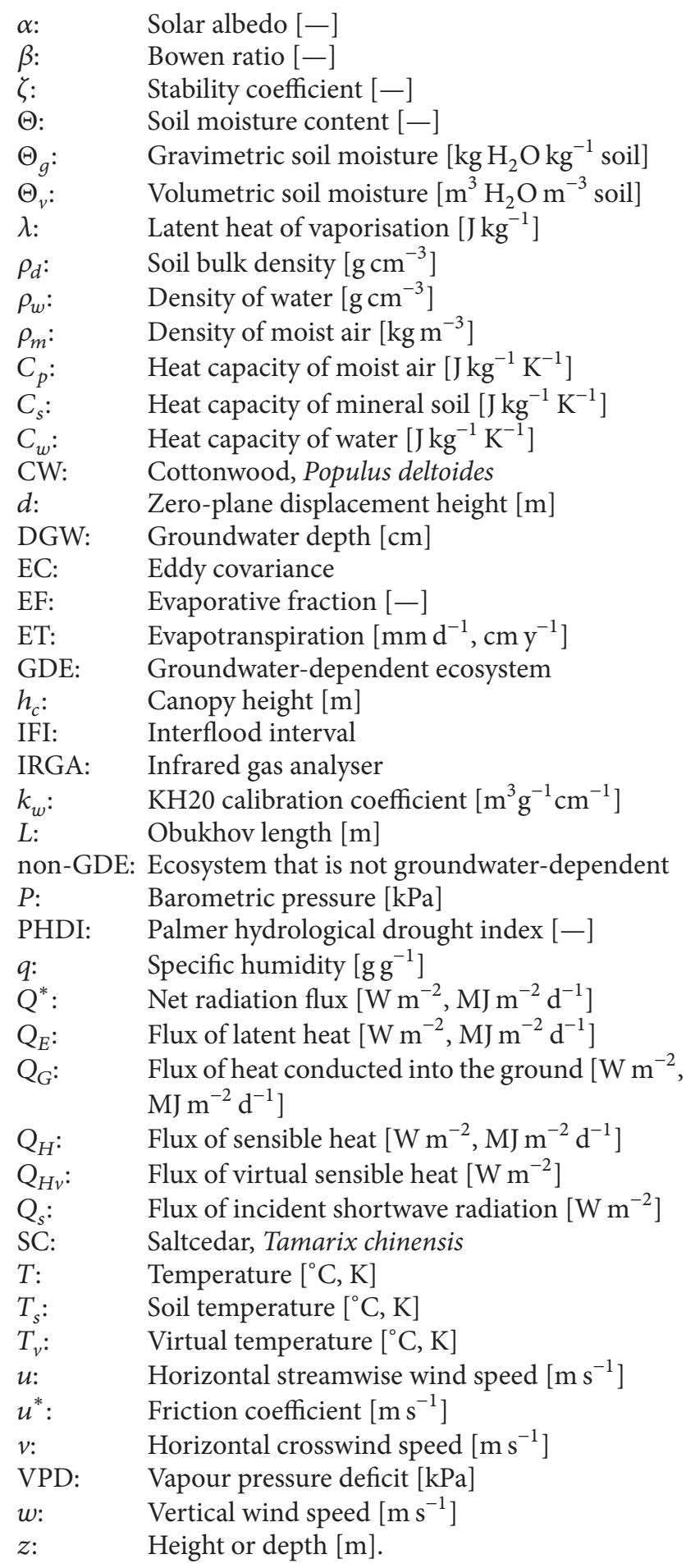

\section{Conflict of Interests}

The authors declare that there is no conflict of interests regarding the publication of this paper.

\section{Acknowledgments}

The authors would like to thank Steve Bowser, Daniel Cooper, John Prueger, William Eichinger, David Gutzler, 
Salim Bawazir, Manuel Molles, Jennifer Schuetz, Clifford Crawford, and Jennifer Shah for their invaluable assistance. In addition, they would like to thank the anonymous reviewer for comments that were helpful in improving this paper. They would like to further thank the following agencies for granting permission to establish these sites: The City of Albuquerque Open Spaces Division, the New Mexico State Land Office, the Middle Rio Grande Conservancy District, New Mexico State Game and Fish, the Sevilleta NWR, and Bosque del Apache NWR. Further appreciation is offered to the Sevilleta Long-Term Ecological Research program, the Bosque Hydrology Group, and the interagency ET workgroup for their ongoing interest and collaboration. This research was funded by NASA award NAG5-6999, the US FWS Bosque Initiative, a US BoR Endangered Species Act research grant, the State of New Mexico Interstate Stream Commission, and an NSF-EPSCoR Research Infrastructure Improvement Award, and NSF DEB\#0080529/DEB\#0217774 to the Sevilleta Long-Term Ecological Research program (SEV717).

\section{References}

[1] D. D. Baldocchi and C. A. Vogel, "Energy and $\mathrm{CO}_{2}$ flux densities above and below a temperate broad-leaved forest and a boreal pine forest," Tree Physiology, vol. 16, no. 1-2, pp. 5-16, 1996.

[2] K. Wilson, D. Baldocchi, M. Aubinet et al., "Energy partitioning between latent and sensible heat flux during the warm season at FLUXNET sites," Water Resources Research, vol. 38, p. 1294, 2002.

[3] C. N. Dahm, J. R. Cleverly, J. E. A. Coonrod, J. R. Thibault, D. E. Mcdonnell, and D. J. Gilroy, "Evapotranspiration at the land/water interface in a semi-arid drainage basin," Freshwater Biology, vol. 47, no. 4, pp. 831-843, 2002.

[4] O. C. Acevedo, O. L. L. Moraes, R. da Silva et al., "Surface-toatmosphere exchange in a river valley environment," Journal of Applied Meteorology and Climatology, vol. 46, no. 8, pp. 11691181, 2007.

[5] D. I. Cooper, W. E. Eichinger, J. Archuleta et al., "Spatial sourcearea analysis of three-dimensional moisture fields from lidar, eddy covariance, and a footprint model," Agricultural and Forest Meteorology, vol. 114, no. 3-4, pp. 213-234, 2003.

[6] D. I. Cooper, W. E. Eichinger, J. Kao et al., "Spatial and temporal properties of water vapor and latent energy flux over a riparian canopy," Agricultural and Forest Meteorology, vol. 105, no. 1-3, pp. 161-183, 2000.

[7] F. Kreith and M. S. Bohn, Principles of Heat Transfer, West Publishing Company, Saint Paul, Minn, USA, 5th edition, 1993.

[8] T. Foken, "The energy balance closure problem: an overview," Ecological Applications, vol. 18, no. 6, pp. 1351-1367, 2008.

[9] W. P. Kustas, J. H. Prueger, J. L. Hatfield, K. Ramalingam, and L. E. Hipps, "Variability in soil heat flux from a mesquite dune site," Agricultural and Forest Meteorology, vol. 103, no. 3, pp. 249-264, 2000.

[10] G. G. Burba, S. B. Verma, and J. Kim, "Surface energy fluxes of Phragmites australis in a prairie wetland," Agricultural and Forest Meteorology, vol. 94, no. 1, pp. 31-51, 1999.

[11] J. R. Cleverly, C. N. Dahm, J. R. Thibault, D. E. McDonnell, and J. E. A. Coonrod, "Riparian ecohydrology: regulation of water flux from the ground to the atmosphere in the Middle Rio Grande, New Mexico," Hydrological Processes, vol. 20, no. 15, pp. 32073225, 2006.

[12] R. Leuning, E. van Gorsel, W. J. Massman, and P. R. Isaac, "Reflections on the surface energy imbalance problem," Agricultural and Forest Meteorology, vol. 156, pp. 65-74, 2012.

[13] N. Kalthoff, M. Fiebig-Wittmaack, C. Meißner et al., “The energy balance, evapo-transpiration and nocturnal dew deposition of an arid valley in the Andes," Journal of Arid Environments, vol. 65, no. 3, pp. 420-443, 2006.

[14] A. P. Sturman and H. A. McGowan, "Observations of dry season surface energy exchanges over a desert clay pan, Queensland, Australia," Journal of Arid Environments, vol. 73, no. 1, pp. 7481, 2009.

[15] M. R. Prater and E. H. DeLucia, "Non-native grasses alter evapotranspiration and energy balance in Great Basin sagebrush communities," Agricultural and Forest Meteorology, vol. 139, no. 1-2, pp. 154-163, 2006.

[16] B. J. Creel, The Rio Grande Compact: It's the Law!, Water Resources Research Institute, Las Cruces, NM, USA, 1999.

[17] S. Kelly, I. Augusten, J. Mann, and L. Katz, "History of the Rio Grande reservoirs in New Mexico: legislation and litigation," Natural Resources Journal, vol. 47, no. 3, pp. 525-613, 2007.

[18] R. B. Jackson, S. R. Carpenter, C. N. Dahm et al., "Water in a changing world," Ecological Applications, vol. 11, no. 4, pp. 1027$1045,2001$.

[19] J. R. Cleverly, C. N. Dahm, J. R. Thibault, D. J. Gilroy, and J. E. A. Coonrod, "Seasonal estimates of actual evapo-transpiration from Tamarix ramosissima stands using three-dimensional eddy covariance," Journal of Arid Environments, vol. 52, no. 2, pp. 181-197, 2002.

[20] C. J. Campbell and W. A. Dick-Peddie, "Comparison of phreatophyte communities on the Rio Grande in New Mexico," Ecology, vol. 45, no. 3, pp. 492-502, 1964.

[21] D. Scurlock, "From the Rio to the Sierra: an environmental history of the Middle Rio Grande Basin," General Technical Report RMRS-GTR-5, USDA Forest Service, Rocky Mountain Research Station, Fort Collins, Colo, USA, 1998.

[22] M. C. Martinet, E. R. Vivoni, J. R. Cleverly, J. R. Thibault, J. F. Schuetz, and C. N. Dahm, "On groundwater fluctuations, evapotranspiration, and understory removal in riparian corridors," Water Resources Research, vol. 45, no. 5, Article ID W05425, 2009.

[23] R. L. Scott, E. A. Edwards, W. J. Shuttleworth, T. E. Huxman, C. Watts, and D. C. Goodrich, "Interannual and seasonal variation in fluxes of water and carbon dioxide from a riparian woodland ecosystem," Agricultural and Forest Meteorology, vol. 122, no. 1-2, pp. 65-84, 2004.

[24] G. C. Topp, J. L. Davis, and A. P. Annan, "Electromagnetic determination of soil water content: measurements in coaxial transmission lines," Water Resources Research, vol. 16, no. 3, pp. 574-582, 1980.

[25] S. J. Zegelin, I. White, and D. R. Jenkins, "Improved field probes for soil water content and electrical conductivity measurement using time domain reflectometry," Water Resources Research, vol. 25, no. 11, pp. 2367-2376, 1989. 
[26] E. Malek and G. E. Bingham, "Partitioning of radiation and energy balance components in an inhomogeneous desert valley,' Journal of Arid Environments, vol. 37, no. 2, pp. 193-207, 1997.

[27] G. W. Moore, J. R. Cleverly, and M. K. Owens, "Nocturnal transpiration in riparian Tamarix thickets authenticated by sap flux, eddy covariance and leaf gas exchange measurements," Tree Physiology, vol. 28, no. 4, pp. 521-528, 2008.

[28] P. Schotanus, F. T. M. Nieuwstadt, and H. A. R. De Bruin, "Temperature measurement with a sonic anemometer and its application to heat and moisture fluxes," Boundary-Layer Meteorology, vol. 26, no. 1, pp. 81-93, 1983.

[29] M. L. Wesely, Eddy correlation measurements in the atmospheric surface layer over agricultural crops [Ph.D. thesis], University of Wisconsin, Madison, Wis, USA, 1970.

[30] W. Massman and R. Clement, "Uncertainty in eddy covariance flux estimates resulting from spectral attenuation," in Handbook of Micrometeorology: A Guide for Surface Flux Measurement and Analysis, X. Lee, W. Massman, and B. Law, Eds., pp. 67100, Kluwer Academic Publishers, Dordrecht, The Netherlands, 2004.

[31] M. E. Jensen, R. D. Burman, and R. G. Allen, Eds., Evapotranspiration and Irrigation Water Requirements, American Society of Civil Engineers, New York, NY, USA, 1990.

[32] E. K. Webb, G. I. Pearman, and R. Leuning, "Correction of flux measurements for density effects due to heat and water vapour transfer," Quarterly Journal Royal Meteorological Society, vol. 106, no. 447, pp. 85-100, 1980.

[33] G. P. Malanson, Riparian Landscapes, Cambridge University Press, New York, NY, USA, 1993.

[34] S. D. Smith, R. K. Monson, and J. E. Anderson, Physiological Ecology of North American Desert Plants, Springer, Heidelberg, Germany, 1997.

[35] D. Eamus, R. Froend, R. Loomes, G. Hose, and B. Murray, "A functional methodology for determining the groundwater regime needed to maintain the health of groundwaterdependent vegetation," Australian Journal of Botany, vol. 54, no. 2, pp. 97-114, 2006.

[36] J. Kochendorfer, E. G. Castillo, E. Haas, W. C. Oechel, and U. K. T. Paw, "Net ecosystem exchange, evapotranspiration and canopy conductance in a riparian forest," Agricultural and Forest Meteorology, vol. 151, no. 5, pp. 544-553, 2011.

[37] J. C. Stromberg, S. J. Lite, R. Marler et al., "Altered stream-flow regimes and invasive plant species: the Tamarix case," Global Ecology and Biogeography, vol. 16, no. 3, pp. 381-393, 2007.

[38] P. B. Shafroth, J. R. Cleverly, T. L. Dudley et al., "Control of Tamarix in the western United States: implications for water salvage, wildlife use, and riparian restoration," Environmental Management, vol. 35, no. 3, pp. 231-246, 2005.

[39] J. Cleverly, "Water use by Tamarix," in Tamarix. A Case Study of Ecological Change in the American West, A. Sher and M. F. Quigley, Eds., pp. 85-98, Oxford University Press, New York, NY, USA, 2013.

[40] J. R. Cleverly and G. D. Russo, "Salt cedar control: exotic species in the San Acacia reach," in Water Resources of the Middle Rio Grande, L. G. Price, P. S. Johnson, and D. Bland, Eds., pp. 7679, New Mexico Bureau of Geology and Mineral Resources, Socorro, NM, USA, 2007.
[41] J. L. Horton, T. E. Kolb, and S. C. Hart, "Physiological response to groundwater depth varies among species and with river flow regulation," Ecological Applications, vol. 11, no. 4, pp. 1046-1059, 2001.

[42] W. T. Pockman and J. S. Sperry, "Vulnerability to xylem cavitation and the distribution of Sonoran desert vegetation," The American Journal of Botany, vol. 87, no. 9, pp. 1287-1299, 2000.

[43] J. L. Horton, T. E. Kolb, and S. C. Hart, "Responses of riparian trees to interannual variation in ground water depth in a semiarid river basin," Plant, Cell and Environment, vol. 24, no. 3, pp. 293-304, 2001.

[44] S. B. Rood, S. Patiño, K. Coombs, and M. T. Tyree, "Branch sacrifice: cavitation-associated drought adaptation of riparian cottonwoods," Trees: Structure and Function, vol. 14, no. 5, pp. $248-257,2000$.

[45] M. L. Scott, P. B. Shafroth, and G. T. Auble, "Responses of riparian cottonwoods to alluvial water table declines," Environmental Management, vol. 23, no. 3, pp. 347-358, 1999.

[46] D. A. Devitt, A. Sala, S. D. Smith, J. Cleverly, L. K. Shaulis, and R. Hammett, "Bowen ratio estimates of evapotranspiration for Tamarix ramosissima stands on the Virgin River in southern Nevada," Water Resources Research, vol. 34, no. 9, pp. 2407-2414, 1998.

[47] S. W. Admiral, P. M. Lafleur, and N. T. Roulet, "Controls on latent heat flux and energy partitioning at a peat bog in eastern Canada," Agricultural and Forest Meteorology, vol. 140, no. 1-4, pp. 308-321, 2006.

[48] A. A. Balogun, J. O. Adegoke, S. Vezhapparambu, M. Mauder, J. P. McFadden, and K. Gallo, "Surface energy balance measurements above an exurban residential neighbourhood of Kansas City, Missouri," Boundary-Layer Meteorology, vol. 133, no. 3, pp. 299-321, 2009.

[49] J. Beringer and N. J. Tapper, "The influence of subtropical cold fronts on the surface energy balance of a semi-arid site," Journal of Arid Environments, vol. 44, no. 4, pp. 437-450, 2000.

[50] G. N. Flerchinger, C. L. Hanson, and J. R. Wight, "Modeling evapotranspiration and surface energy budgets across a watershed," Water Resources Research, vol. 32, no. 8, pp. 2539-2548, 1996.

[51] B. Han, S. H. Lu, and Y. H. Ao, "Analysis on the interaction between turbulence and secondary circulation of the surface layer at Jinta oasis in summer," Advances in Atmospheric Sciences, vol. 27, no. 3, pp. 605-620, 2010.

[52] T. W. Brakke, S. B. Verma, and N. J. Rosenberg, "Local and regional components of sensible heat advection," Journal of Applied Meteorology, vol. 17, no. 7, pp. 955-963, 1978.

[53] S. B. Verma, N. J. Rosenberg, and B. L. Blad, "Turbulent exchange coefficients for sensible heat and water vapor under advective conditions," Journal of Applied Meteorology, vol. 17, no. 3, pp. 330-338, 1978.

[54] F. Qi, M. C. Zhuo, and H. Y. Xi, "Analysis of an oasis microclimate in China's hyperarid zone," Environmental Geology, vol. 58, no. 5, pp. 963-972, 2009.

[55] P. L. Nagler, R. L. Scott, C. Westenburg, J. R. Cleverly, E. P. Glenn, and A. R. Huete, "Evapotranspiration on western U.S. rivers estimated using the Enhanced Vegetation Index from MODIS and data from eddy covariance and Bowen ratio flux 
towers," Remote Sensing of Environment, vol. 97, no. 3, pp. 337351, 2005.

[56] J. R. Cleverly, S. D. Smith, A. Sala, and D. A. Devitt, "Invasive capacity of Tamarix ramosissima in a Mojave Desert floodplain: the role of drought," Oecologia, vol. 111, no. 1, pp. 12-18, 1997.

[57] C.-H. Cheng, F. Nnadi, and Y.-A. Liou, "Energy budget on various land use areas using reanalysis data in Florida," Advances in Meteorology, vol. 2014, Article ID 232457, 13 pages, 2014.

[58] S. Chen, J. Chen, G. Lin et al., "Energy balance and partition in Inner Mongolia steppe ecosystems with different land use types," Agricultural and Forest Meteorology, vol. 149, no. 11, pp. 1800-1809, 2009.

[59] S. J. Gray, J. L. Betancourt, C. L. Fastie, and S. T. Jackson, "Patterns and sources of multidecadal oscillations in droughtsensitive tree-ring records from the Central and Southern Rocky Mountains," Geophysical Research Letters, vol. 30, no. 6, article 1316, 2003. 

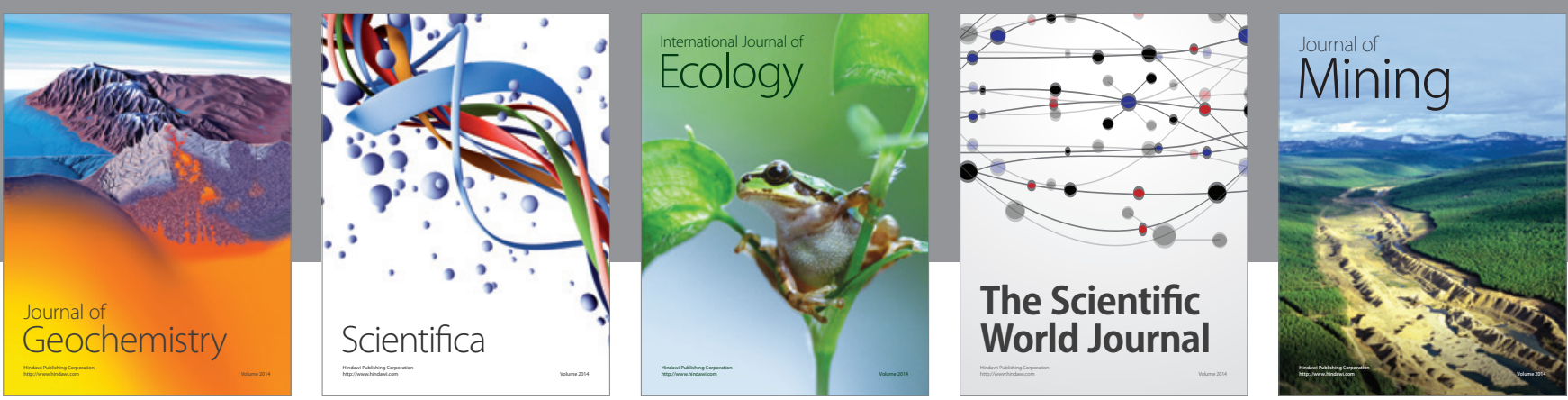

The Scientific World Journal
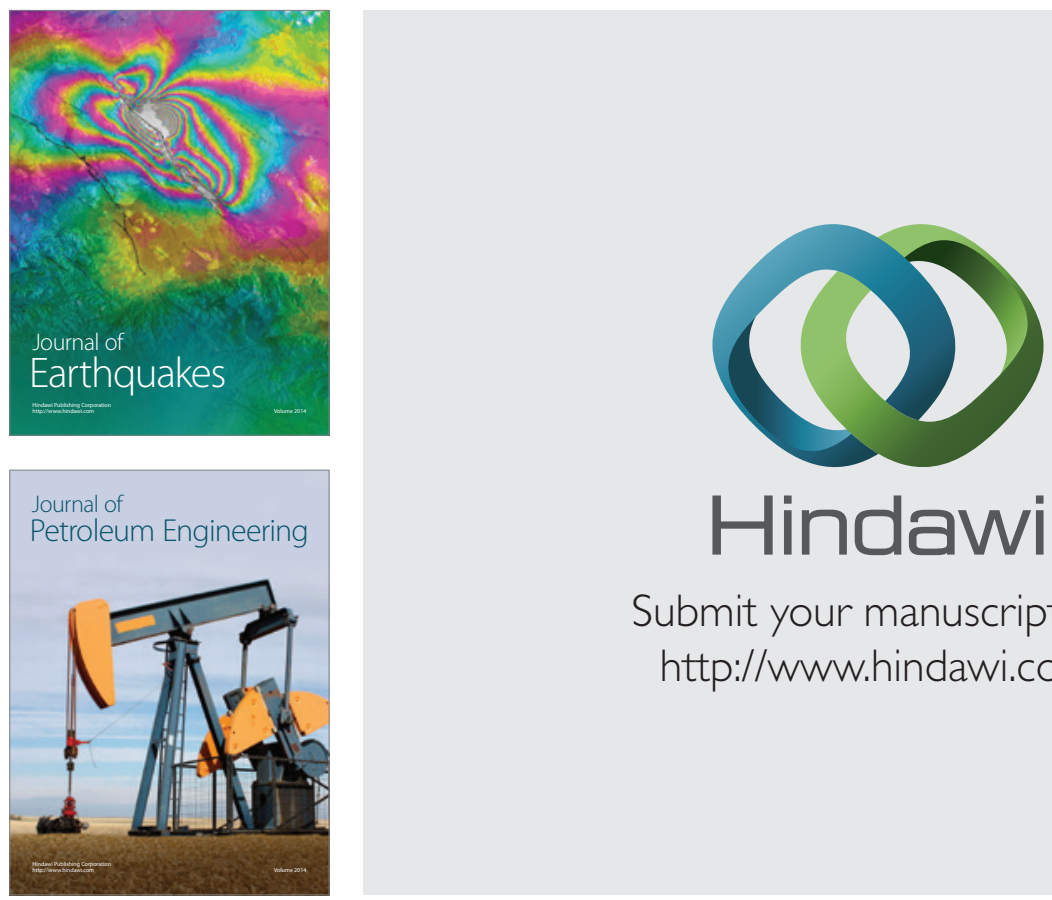

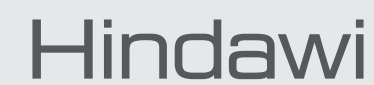

Submit your manuscripts at

http://www.hindawi.com
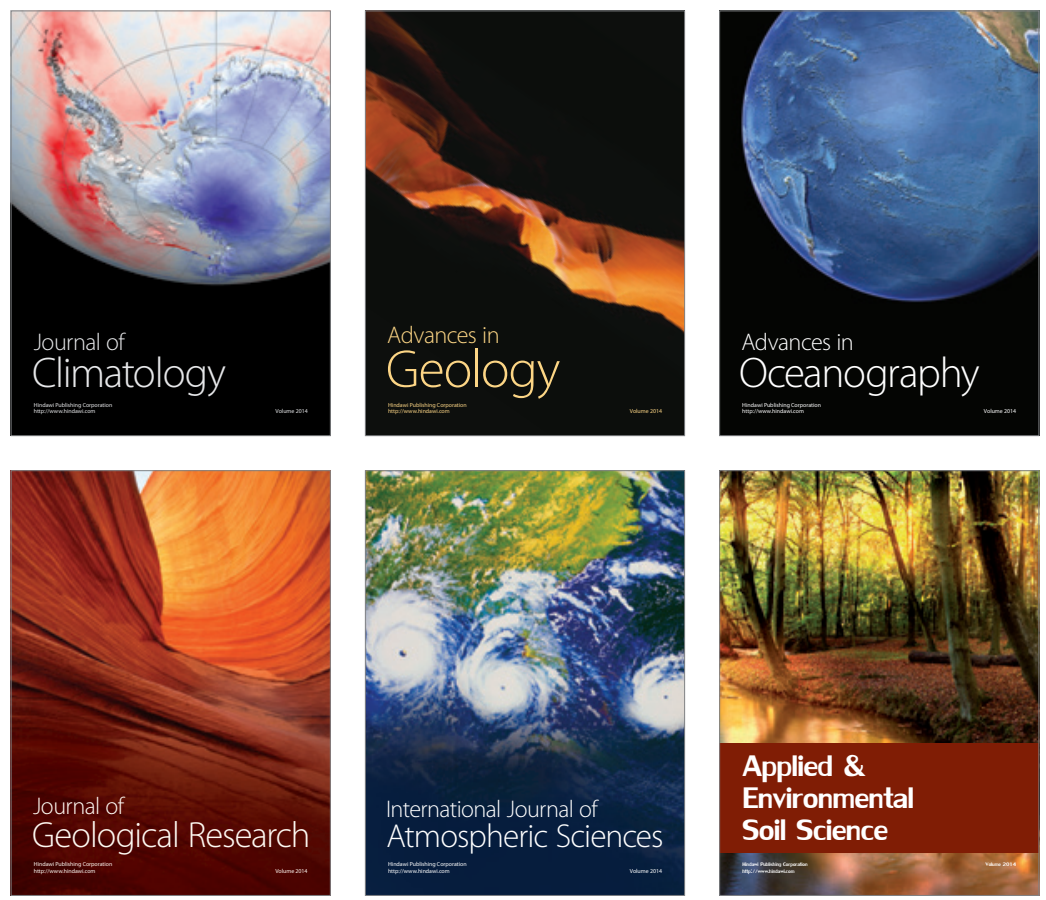
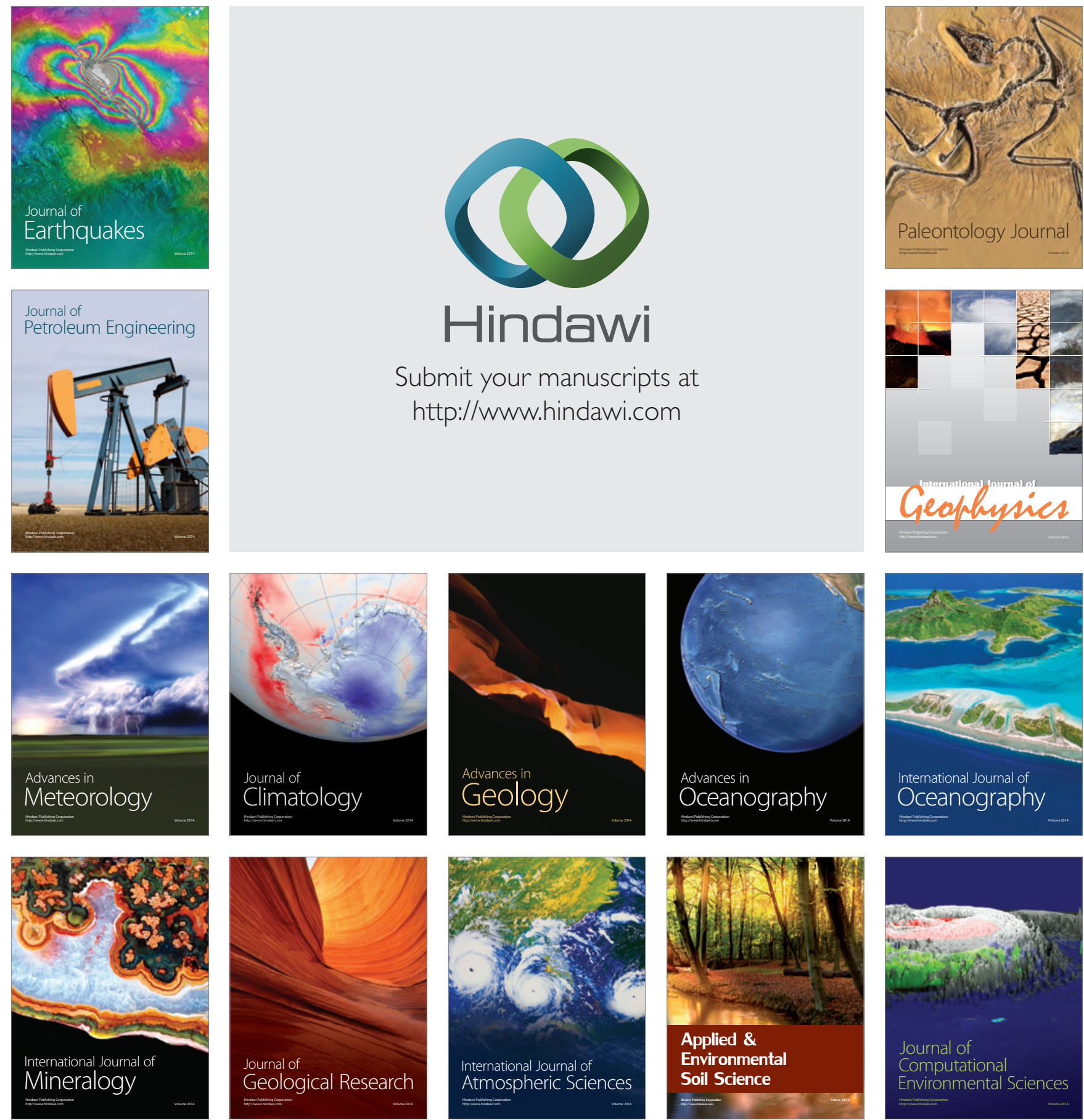